\title{
Formation of Gold(III) Alkyls from Gold Alkoxide Complexes
}

\author{
Isabelle Chambrier, ${ }^{\dagger}$ Dragoş-Adrian Roşca, ${ }^{\dagger}{ }^{\S}$ Julio Fernandez-Cestau, ${ }^{\dagger}$ David L. Hughes, ${ }^{\dagger}$ \\ Peter H. M. Budzelaar, ${ }^{*},{ }^{,}, \#$ and Manfred Bochmann ${ }^{*}, \dagger$ \\ ${ }^{\dagger}$ School of Chemistry, University of East Anglia, Norwich NR4 7TJ, U.K. \\ ${ }^{\ddagger}$ Department of Chemistry, University of Manitoba, Winnipeg, Manitoba R3T 2N2, Canada
}

\section{Supporting Information}

\begin{abstract}
The gold(III) methoxide complex $\left(\mathrm{C}^{\wedge} \mathrm{N}^{\wedge} \mathrm{C}\right)$ AuOMe (1) reacts with tris $(p$-tolyl)phosphine in benzene at room temperature under $\mathrm{O}$ abstraction to give the methylgold product $\left(\mathrm{C}^{\wedge} \mathrm{N}^{\wedge} \mathrm{C}\right)$ AuMe (2) together with $\mathrm{O}=\mathrm{P}(p \text {-tol })_{3}\left(\left(\mathrm{C}^{\wedge} \mathrm{N}^{\wedge} \mathrm{C}\right)=\left[2,6-\left(\mathrm{C}_{6} \mathrm{H}_{3}{ }^{t} \mathrm{Bu}-4\right)_{2} \text { pyridine }\right]^{2-}\right)$. Calculations show that this reaction is energetically favorable $(\Delta G=$ $\left.-32.3 \mathrm{kcal} \mathrm{mol}^{-1}\right)$. The side products in this reaction, the $\mathrm{Au}(\mathrm{II})$ complex $\left[\mathrm{Au}\left(\mathrm{C}^{\wedge} \mathrm{N}^{\wedge} \mathrm{C}\right)\right]_{2}$ (3) and the phosphorane ( $p$-tol $)_{3} \mathrm{P}(\mathrm{OMe})_{2}$, suggest that at least two reaction pathways may operate, including one involving $\left(\mathrm{C}^{\wedge} \mathrm{N}^{\wedge} \mathrm{C}\right) \mathrm{Au} u^{\bullet}$ radicals. Attempts to model the reaction by DFT methods showed that $\mathrm{PPh}_{3}$ can approach 1 to give a near-linear $\mathrm{Au}-\mathrm{O}-\mathrm{P}$ arrangement, without phosphine coordination to gold. The
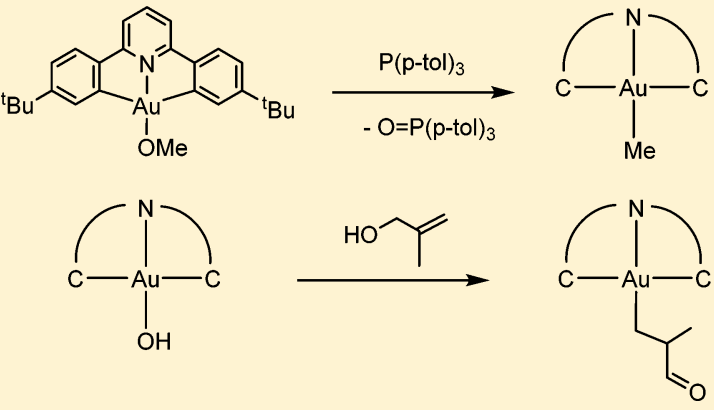
exclusively a mixture of 3 and $(p \text {-tol })_{3} \mathrm{P}(\mathrm{OEt})_{2}$. Whereas the reaction of $\left(\mathrm{C}^{\wedge} \mathrm{N}^{\wedge} \mathrm{C}\right) \mathrm{AuOR}\left(\mathrm{R}=\mathrm{Bu}^{\mathrm{t}}, p\right.$ - $\left.\mathrm{C}_{6} \mathrm{H}_{4} \mathrm{~F}\right)$ with $\mathrm{P}(p \text {-tol })_{3}$ proceeds over a period of hours, compounds with $\mathrm{R}=\mathrm{CH}_{2} \mathrm{CF}_{3}, \mathrm{CH}\left(\mathrm{CF}_{3}\right)_{2}$ react almost instantaneously, to give 3 and $\mathrm{O}=\mathrm{P}(p$ tol $)_{3}$. In chlorinated solvents, treatment of the alkoxides $\left(\mathrm{C}^{\wedge} \mathrm{N}^{\wedge} \mathrm{C}\right) \mathrm{AuOR}$ with phosphines generates $\left[\left(\mathrm{C}^{\wedge} \mathrm{N}^{\wedge} \mathrm{C}\right) \mathrm{Au}(\mathrm{PR})\right] \mathrm{Cl}$, via $\mathrm{Cl}$ abstraction from the solvent. Attempts to extend the synthesis of gold(III) alkoxides to allyl alcohols were unsuccessful; the reaction of $\left(\mathrm{C}^{\wedge} \mathrm{N}^{\wedge} \mathrm{C}\right) \mathrm{AuOH}$ with an excess of $\mathrm{CH}_{2}=\mathrm{CHCH}_{2} \mathrm{OH}$ in toluene led instead to allyl alcohol isomerization to give a mixture of gold alkyls, $\left(\mathrm{C}^{\wedge} \mathrm{N}^{\wedge} \mathrm{C}\right) \mathrm{AuR}^{\prime}\left(\mathrm{R}^{\prime}=-\mathrm{CH}_{2} \mathrm{CH}_{2} \mathrm{CHO}(\mathbf{1 0}),-\mathrm{CH}_{2} \mathrm{CH}\left(\mathrm{CH}_{2} \mathrm{OH}\right) \mathrm{OCH}_{2} \mathrm{CH}_{2} \mathrm{CH}_{2} \quad(\mathbf{1 1})\right)$, while 2-methallyl alcohol affords $\mathrm{R}^{\prime}=\mathrm{CH}_{2} \mathrm{CH}(\mathrm{Me}) \mathrm{CHO}$ (12). The crystal structure of 11 was determined. The formation of $\mathrm{Au}-\mathrm{C}$ instead of the expected $\mathrm{Au}-\mathrm{O}$ products is in line with the trend in metal-ligand bond dissociation energies for $\mathrm{Au}(\mathrm{III}): \mathrm{M}-\mathrm{H}>$ $\mathrm{M}-\mathrm{C}>\mathrm{M}-\mathrm{O}$.
\end{abstract}

\section{INTRODUCTION}

The application of gold complexes as mediators or catalysts in organic transformations has seen a rapid rise in the last 15 years. ${ }^{1}$ An important factor in this development is the high electronegativity of gold, which is almost identical with that of carbon and gives rise to highly covalent $\mathrm{Au}-\mathrm{C}$ bonds, such that cations $\mathrm{LAu}^{+}$have been characterized as "carbophilic electrophiles". ${ }^{2}$ Apart from the widespread application of gold(I) catalysts, gold(III) complexes are used in many catalytic transformations. ${ }^{3}$ However, although $\mathrm{Au}$ (III) is isoelectronic and often isostructural with its $\mathrm{Pt}$ (II) analogues, it is becoming increasingly apparent that simple $\mathrm{Pt}(\mathrm{II}) / \mathrm{Au}(\mathrm{III})$ analogies concerning reaction mechanisms can be quite misleading; the reaction pathways of gold(III) are only just beginning to be explored. ${ }^{4,5}$ Different energetic driving forces operate for gold and platinum; for example, whereas for $\mathrm{Pt}(\mathrm{II})$ the bond dissociation energies decrease in the order $\mathrm{M}-\mathrm{O}>$ $\mathrm{M}-\mathrm{H}>\mathrm{M}-\mathrm{C}$, gold(III) follows the order $\mathrm{M}-\mathrm{H}>\mathrm{M}-\mathrm{C}>$ $\mathrm{M}-\mathrm{O}{ }^{6}$ These energetic differences will determine product formation.

As we have recently shown, in line with this ordering of bond strengths $\left(\mathrm{C}^{\wedge} \mathrm{N}^{\wedge} \mathrm{C}\right)$ gold(III) pincer complexes allow the transformation of gold hydroxides into gold hydrides simply by
O abstraction with phosphines $\left(\left(\mathrm{C}^{\wedge} \mathrm{N}^{\wedge} \mathrm{C}\right)=\left[2,6-\left(\mathrm{C}_{6} \mathrm{H}_{3}{ }^{t} \mathrm{Bu}-\right.\right.\right.$ $4)_{2}$ pyridine $\left.]^{2-}\right){ }^{7}$ Following the same bond strength trend, gold hydrides can even be formed from suitable reactive gold-carbon compounds, such as $\mathrm{Au}-\mathrm{COOH}$ species, where facile transformation to the hydride by $\mathrm{CO}_{2}$ elimination was observed. ${ }^{8}$ Calculations also show that the $\mathrm{O}$ abstraction from the gold methoxide 1 to give the gold methyl complex $\mathbf{2}$ is energetically favorable (Scheme 1).

We decided to explore whether this computationally predicted transformation could indeed be realized in practice and whether it might provide a possible alternative pathway to gold alkyl complexes without the need for conventional alkylating agents based on metal alkyls.

\section{RESULTS AND DISCUSSION}

Monitoring the reaction of $\left(\mathrm{C}^{\wedge} \mathrm{N}^{\wedge} \mathrm{C}\right) \mathrm{AuOMe}(1)$ with tris $(p$ tolyl)phosphine as reducing agent in $\mathrm{C}_{6} \mathrm{D}_{6}$ at $25{ }^{\circ} \mathrm{C}$ by ${ }^{1} \mathrm{H}$ NMR spectroscopy shows the disappearance of $\mathbf{1}$ and formation of $\mathbf{2}$, in line with the predicted reactivity trend. It is convenient to follow these reactions by monitoring the signal

Received: February 1, 2017 
Scheme 1. Conversion of $\mathrm{Au}{ }^{\mathrm{III}}-\mathrm{O}$ into $\mathrm{Au}{ }^{\mathrm{III}}-\mathrm{H}$ and $\mathrm{Au}{ }^{\mathrm{III}}-\mathrm{C}$ Compounds and Calculated Energy Balances for These Transformations $^{a}$

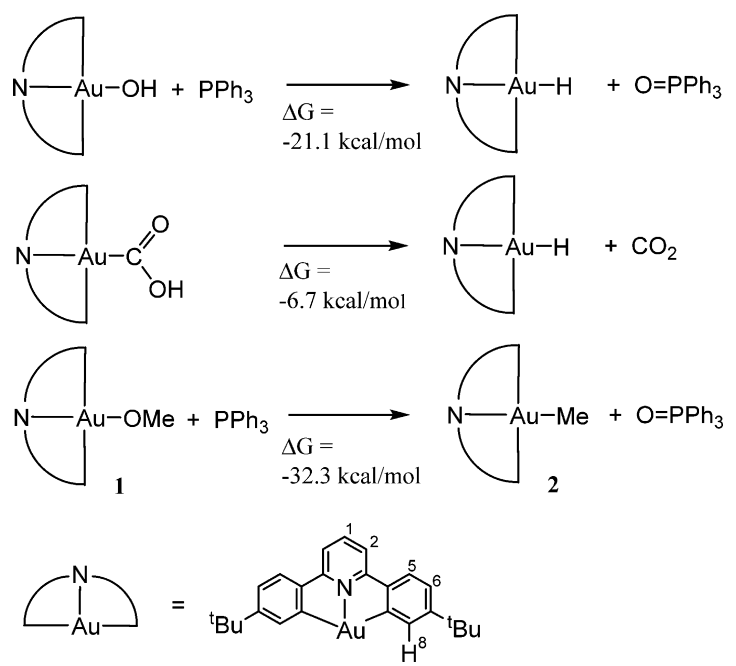

${ }^{a_{T}}$ The pincer ligand structure shows the atomic numbering scheme used for the assignment of ${ }^{1} \mathrm{H}$ NMR spectra.

for the $\mathrm{H} 8$ proton $(\mathrm{d}, J=2 \mathrm{~Hz}$ ). For complex 1 this signal is found at $\delta 8.44$. After $72 \mathrm{~h}$ this signal is diminished, and a new signal has appeared at $\delta 8.18$, with the same small through-ring coupling (Figure 1). At the same time, the methoxy signal at $\delta 4.78$ is replaced by the methyl signal at $\delta 1.94$. These assignments were confirmed by comparison with the spectrum of an independently prepared sample of the known ${ }^{9}$ methyl complex 2. The ${ }^{31} \mathrm{P}$ NMR spectra also showed the conversion of $(p \text {-tolyl })_{3} \mathrm{P}(\delta-7.6)$ into $(p \text {-tolyl })_{3} \mathrm{P}=\mathrm{O}(\delta 25.3)$; however, another phosphorus signal was also apparent, at $\delta-52.5$, which was assigned to $\operatorname{dimethoxytris}(p$-tolyl $)$ phosphorane, $(p \text {-tolyl })_{3} \mathrm{P}(\mathrm{OMe})_{2}{ }^{10}$
This indicated a more complex reaction than was postulated for the $\mathrm{O}$ abstraction of $\left(\mathrm{C}^{\wedge} \mathrm{N}^{\wedge} \mathrm{C}\right) \mathrm{AuOH}$ to the corresponding gold hydride, where kinetic and isotope labeling studies had suggested a second-order, concerted O-extrusion pathway. The existence of competing alternative reaction channels in the transformation of $\mathbf{1}$ to $\mathbf{2}$ was also indicated by the appearance of signals due to the known ${ }^{11} \mathrm{Au}(\mathrm{II})$ complex $\left(\mathrm{C}^{\wedge} \mathrm{N}^{\wedge} \mathrm{C}\right) \mathrm{Au}-$ $\mathrm{Au}\left(\mathrm{C}^{\wedge} \mathrm{N}^{\wedge} \mathrm{C}\right)$ (3). The final 2:3 molar ratio was 3:1. The formation of this $\mathrm{Au}(\mathrm{II})$ product, as well as the formation of $(p \text {-tolyl })_{3} \mathrm{P}(\mathrm{OMe})_{2}$, hint at the participation of single-electron pathways in this reaction, with transfer of $\mathrm{MeO}$ radicals. The possible contribution of hydrolysis of ( $p$-tolyl $)_{3} \mathrm{P}(\mathrm{OMe})_{2}$ as a source for $(p \text {-tolyl })_{3} \mathrm{P}=\mathrm{O}$ proved difficult to exclude.

A plausible mechanistic scenario is shown in Scheme 2. From the product distribution it seems clear that at least two

Scheme 2. Possible Reaction Pathways in the O Abstraction from Gold(III) Methoxide

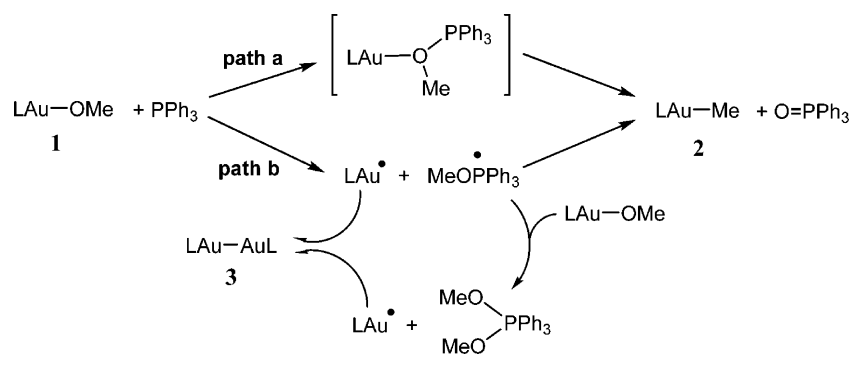

competing pathways may be operational. On the basis of the analogy with the deoxygenation of $\left(\mathrm{C}^{\wedge} \mathrm{N}^{\wedge} \mathrm{C}\right) \mathrm{AuOH}$ by phosphines, which involved a concerted reaction step without prior phosphine coordination, ${ }^{7}$ a direct attack of the phosphine on the OMe ligand of 1 cannot be excluded (Scheme 2, path a). However, given the formation of $(\mathrm{MeO})_{2} \mathrm{P}(p \text {-tol })_{3}$ as one of the products, methoxide transfer to the phosphine clearly also

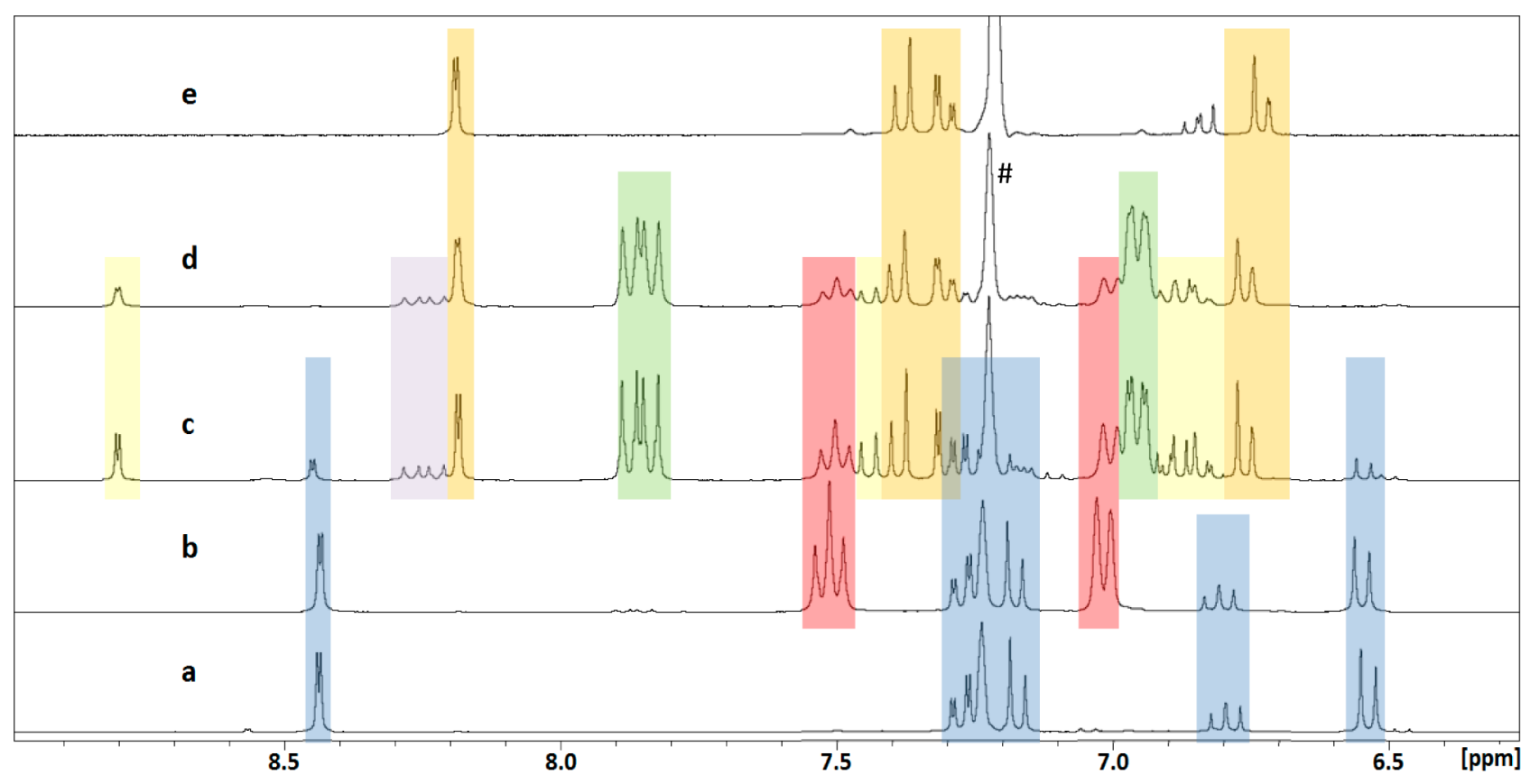

Figure 1. ${ }^{1} \mathrm{H}$ NMR spectra $\left(6.5-9\right.$ ppm region, $\left.\mathrm{C}_{6} \mathrm{D}_{6}, 300 \mathrm{MHz}\right)$ monitoring the reaction of $\left(\mathrm{C}^{\wedge} \mathrm{N}^{\wedge} \mathrm{C}\right) \mathrm{AuOMe}$ with $\left(p\right.$-tolyl) ${ }_{3} \mathrm{P}$ : (a) spectrum of $\mathbf{1}$; (b) spectrum immediately after addition of $(p \text {-tolyl })_{3} \mathrm{P}$; (c) spectrum after $72 \mathrm{~h}$; (d) spectrum after 7 days; (e) spectrum of $\left(\mathrm{C}^{\wedge} \mathrm{N}^{\wedge} \mathrm{C}\right)$ AuMe $(2)$. Color scheme: blue, 1; orange, 2 ; red, $\mathrm{P}(\mathrm{tol})_{3}$; green, $\mathrm{O}=\mathrm{P}(\mathrm{tol})_{3}$; purple, $\mathrm{P}(\mathrm{tol})_{3}(\mathrm{OMe})_{2}$; yellow, 3. \# indicates the solvent peak (benzene). 
plays a role, which implies either homolytic or heterolytic $\mathrm{Au}-\mathrm{O}$ bond cleavage. Since the reaction proceeds smoothly in nonpolar solvents such as benzene, and given the relative weakness of the $\mathrm{Au}-\mathrm{O}$ bond $\left(50 \mathrm{kcal} \mathrm{mol}^{-1}\right.$ in 1, in comparison to the $\mathrm{Au}-\mathrm{C}$ value of $63 \mathrm{kcal} \mathrm{mol}^{-1}$ in 2), ${ }^{6}$ bond homolysis seems at least possible, generating the gold(II) radical species $\left(\mathrm{C}^{\wedge} \mathrm{N}^{\wedge} \mathrm{C}\right) \mathrm{Au}^{\bullet}$ (Scheme 2, path b). The possible involvement of $\left(\mathrm{C}^{\wedge} \mathrm{N}^{\wedge} \mathrm{C}\right) \mathrm{Au}^{\bullet}$ gains support by previous observation of the involvement of this $\mathrm{Au}$ (II) species in the electrochemical reduction of $\mathrm{Au}(\mathrm{III}){ }^{12}$ as well as in the radical-initiated trans addition of $\mathrm{Au}-\mathrm{H}$ bonds to alkynes. $^{13}$

We made numerous attempts to model the observed $\mathrm{O}$ transfer to phosphines by DFT methods, using both $\mathrm{PPh}_{3}$ and the more reducing $\mathrm{PMe}_{3}$ as models. For the direct $\mathrm{O}$ transfer, pathway a, a transition state was found, but at a comparatively high energy $\left(\Delta G^{\ddagger}=39.7 \mathrm{kcal} \mathrm{mol}^{-1}\right)$, close to that required for $\mathrm{Au}-\mathrm{O}$ bond homolysis $\left(\Delta G=52.1 \mathrm{kcal} \mathrm{mol}^{-1}\right.$ calculated at the same level). The approach of $\mathrm{PPh}_{3}$ to 1 gives a near-linear $\mathrm{Au}-\mathrm{O}-\mathrm{P}$ arrangement (Figure 2). The movement associated

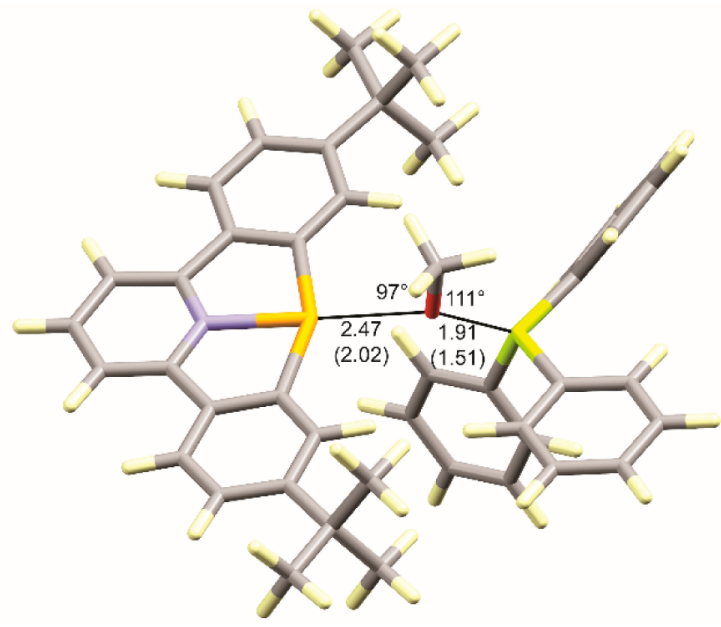

Figure 2. Optimized transition state geometry for the postulated $\mathrm{O}$ abstraction via Scheme 2, path a, showing bond lengths $(\AA)$ and angles (deg) around $\mathrm{O}$. Distances to $\mathrm{O}$ in the reactant and product are given in parentheses.

with the transition state is nearly pure $\mathrm{O}$ translation between $\mathrm{Au}$ and $\mathrm{P}$, with the Me group hardly moving. Following this motion toward Au leads back to the LAuOMe reactant, as expected. Following it toward P leads to "LAu $+\mathrm{MeOPR}_{3}$ ", as suggested in pathway $\mathrm{b}$. Undoubtedly a subsequent Me transfer from $\mathrm{MeOPR}_{3}$ to $\mathrm{Au}$ would be facile. Other possible intermediates were also investigated, including the five-coordinate phosphorus species $\mathrm{Ph}_{3} \mathrm{P}(\mathrm{OMe})(\mathrm{AuL})$, which might be postulated to explain the methoxide transfer from $\mathrm{Au}$ to $\mathrm{P}$ without the need for $\mathrm{Au}-\mathrm{O}$ bond homolysis. This would involve formally a phosphine insertion into the $\mathrm{Au}-\mathrm{O}$ bond; however, no realistic path to such an intermediate could be identified. Calculating alternative pathways involving oddelectron $\mathrm{Au}(\mathrm{II})$ and $\mathrm{MeO}^{\bullet}$ radical species proved problematic and did not result in a clearly identifiable low-energy trajectory.

The gold(III) alkoxide starting materials are generally most conveniently prepared either from the gold chloride (eq 1) or from the hydroxide $\left(\mathrm{C}^{\wedge} \mathrm{N}^{\wedge} \mathrm{C}\right) \mathrm{AuOH}^{14}$ with $\mathrm{ROH}$ in toluene (eq 2), to give the alkoxides $\mathbf{4 - 8}$.

$$
\begin{gathered}
\left(\mathrm{C}^{\wedge} \mathrm{N}^{\wedge} \mathrm{C}\right) \mathrm{AuCl}+\mathrm{RONa} \\
\stackrel{\mathrm{THF}, \text { room temp }}{\longrightarrow} \quad\left(\mathrm{C}^{\wedge} \mathrm{N}^{\wedge} \mathrm{C}\right) \mathrm{AuOR}+\mathrm{NaCl} \\
\mathrm{R}=\mathrm{Et}(\mathbf{4}), \mathrm{Bu}^{\mathrm{t}}(\mathbf{5}), \mathrm{C}_{6} \mathrm{H}_{4} \mathrm{~F}-p(\mathbf{6}) \\
\left(\mathrm{C}^{\wedge} \mathrm{N}^{\wedge} \mathrm{C}\right) \mathrm{AuOH}+\mathrm{ROH} \\
\stackrel{\text { toluene, room temp }}{\longrightarrow} \mathrm{R}=\mathrm{OCH}_{2} \mathrm{CF}_{3}(\mathbf{7}), \mathrm{OCH}\left(\mathrm{CF}_{3}\right)_{2}(\mathbf{8})
\end{gathered}
$$

This preparation from the hydroxide worked well when $\mathrm{R}$ = fluoroalkyl but failed to give a clean product for $\mathrm{R}=$ ethyl, benzyl; the reaction of $\left(\mathrm{C}^{\wedge} \mathrm{N}^{\wedge} \mathrm{C}\right) \mathrm{AuCl}$ with the sodium salt of allyl alcohol also failed. The reaction of $\left(\mathrm{C}^{\wedge} \mathrm{N}^{\wedge} \mathrm{C}\right) \mathrm{AuX}(\mathrm{X}=\mathrm{Cl}$, $\mathrm{OAc}^{\mathrm{F}}$ ) with $p-\mathrm{ClC}_{6} \mathrm{H}_{4} \mathrm{CH}_{2} \mathrm{ONa}$ led exclusively to reduction to the $\mathrm{Au}(\mathrm{II})$ product 3 , even at low temperature (THF, $-20^{\circ} \mathrm{C}$ ), while no reaction was observed with $p-\mathrm{ClC}_{6} \mathrm{H}_{4} \mathrm{CH}_{2} \mathrm{OH}$ in the presence of triethylamine.

The scope of the $\mathrm{O}$ abstraction was explored for the alkoxide starting materials $\left(\mathrm{C}^{\wedge} \mathrm{N}^{\wedge} \mathrm{C}\right) \mathrm{AuOR}\left(\mathrm{R}=\mathrm{Et}(4),{ }^{t} \mathrm{Bu}\right.$ (5), $p$ - $\left.\mathrm{FC}_{6} \mathrm{H}_{4}(6), \mathrm{CH}_{2} \mathrm{CF}_{3}(7), \mathrm{CH}\left(\mathrm{CF}_{3}\right)_{2}(8)\right)$. The contributions of pathways $\mathrm{a}$ and $\mathrm{b}$ to the outcome of the overall reaction appear to depend on the nature of the alkoxide ligand. The ethoxide $\left(\mathrm{C}^{\wedge} \mathrm{N}^{\wedge} \mathrm{C}\right)$ AuOEt (4) reacted with $\mathrm{P}(p \text {-tol })_{3}$ under conditions identical with those employed for $\mathbf{1}$ in benzene over a period of $72 \mathrm{~h}$ to give exclusively the $\mathrm{Au}$ (II) dimer 3 and $(\mathrm{EtO})_{2} \mathrm{P}(p \text {-tol })_{3}$, without formation of $\left(\mathrm{C}^{\wedge} \mathrm{N}^{\wedge} \mathrm{C}\right)$ $\mathrm{AuEt}^{9}$ in detectable quantities. The analogous reaction with $\left(\mathrm{C}^{\wedge} \mathrm{N}^{\wedge} \mathrm{C}\right) \mathrm{AuO}^{t} \mathrm{Bu}(5)$ gave mainly 3 together with $(p \text {-tol })_{3} \mathrm{P}=\mathrm{O}$ but the reaction only went to about $60 \%$ completion, even after several days. In order to ascertain the presence or absence of $\left(\mathrm{C}^{\wedge} \mathrm{N}^{\wedge} \mathrm{C}\right) \mathrm{Au}{ }^{t} \mathrm{Bu}(9)$ among the possible products, complex 9 was prepared independently from the trifluoroacetate $\left(\mathrm{C}^{\wedge} \mathrm{N}^{\wedge} \mathrm{C}\right)$ $\mathrm{AuOAc}{ }^{\mathrm{F}}$ and ${ }^{t} \mathrm{BuMgCl}$ at $-20{ }^{\circ} \mathrm{C}$ as a colorless crystalline solid. ${ }^{15}$ Its NMR spectrum confirmed, however, that 9 was not formed in the reaction of $\mathbf{5}$ with phosphines. Similarly, the reaction of $\left(\mathrm{C}^{\wedge} \mathrm{N}^{\wedge} \mathrm{C}\right) \mathrm{AuOC}_{6} \mathrm{H}_{4} \mathrm{~F}$ (6) with $\mathrm{P}(p \text {-tol })_{3}$ gave exclusively the $\mathrm{Au}(\mathrm{II})$ product 3 and $(p \text {-tol })_{3} \mathrm{PO}$.

In contrast to the slow reactions of $\mathbf{4}$ and $\mathbf{5}$, the trifluoroethoxide $\left(\mathrm{C}^{\wedge} \mathrm{N}^{\wedge} \mathrm{C}\right) \mathrm{AuOCH}_{2} \mathrm{CF}_{3}$ (7) reacted almost instantaneously with the phosphine, again forming exclusively the $\mathrm{Au}(\mathrm{II})$ complex 3, although in this case the oxidation product was $(p \text {-tol })_{3} \mathrm{P}=\mathrm{O}$, whereas the expected phosphorane ( $p$-tol $)_{3} \mathrm{P}\left(\mathrm{OCH}_{2} \mathrm{CF}_{3}\right)_{2}$ was not detected.

In all of these reactions the correct choice of solvent is important. Although solutions of gold alkoxides $\left(\mathrm{C}^{\wedge} \mathrm{N}^{\wedge} \mathrm{C}\right) \mathrm{AuOR}$ in $\mathrm{CH}_{2} \mathrm{Cl}_{2}$ are stable for several hours, in the presence of phosphines the use of chlorinated solvents invariably led to chlorine abstraction from the solvent and the formation of $\left[\left(\mathrm{C}^{\wedge} \mathrm{N}^{\wedge} \mathrm{C}\right)\right.$ $\left.\mathrm{Au}\left\{\mathrm{P}(\text { tol }-p)_{3}\right\}\right] \mathrm{Cl}$, via $\left(\mathrm{C}^{\wedge} \mathrm{N}^{\wedge} \mathrm{C}\right) \mathrm{AuCl}$ as intermediate (eq 3$)$.

$$
\begin{aligned}
& \left(\mathrm{C}^{\wedge} \mathrm{N}^{\wedge} \mathrm{C}\right) \mathrm{AuCl}+\mathrm{P}(p \text {-tol })_{3} \\
& \stackrel{\mathrm{CH}_{2} \mathrm{Cl}_{2}}{\longrightarrow}\left[\left(\mathrm{C}^{\wedge} \mathrm{N}^{\wedge} \mathrm{C}\right) \mathrm{Au}\left\{\mathrm{P}(p \text {-tol })_{3}\right\}\right]^{+} \mathrm{Cl}^{-}
\end{aligned}
$$

Unlike the reactions with benzylic alcohols, attempts to make gold complexes using allyl alcohols proved more successful. Whereas the reaction between $\left(\mathrm{C}^{\wedge} \mathrm{N}^{\wedge} \mathrm{C}\right) \mathrm{AuCl}$ and $\mathrm{NaOCH}_{2} \mathrm{CH}=$ $\mathrm{CH}_{2}$ led to electron transfer to afford exclusively the $\mathrm{Au}(\mathrm{II})$ dimer 3, treating $\left(\mathrm{C}^{\wedge} \mathrm{N}^{\wedge} \mathrm{C}\right) \mathrm{AuOH}$ and excess allyl alcohol in toluene in the presence of molecular sieves gave a mixture of two products, 10 and $\mathbf{1 1}$. However, none of these products was the expected gold allyloxide complex. The compounds were 


\section{Scheme 3. Reactions of Gold Hydroxides with Allyl Alcohols}

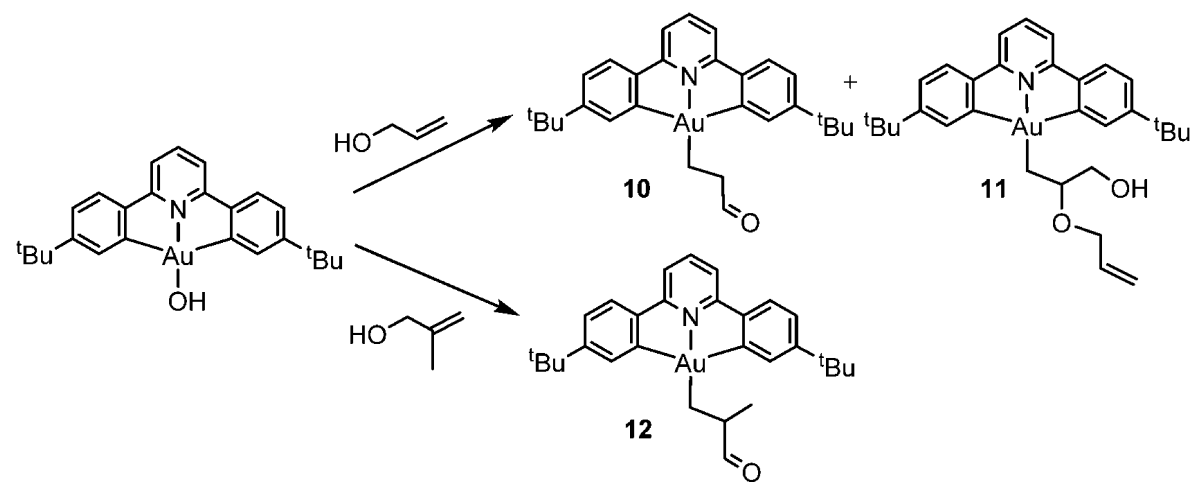
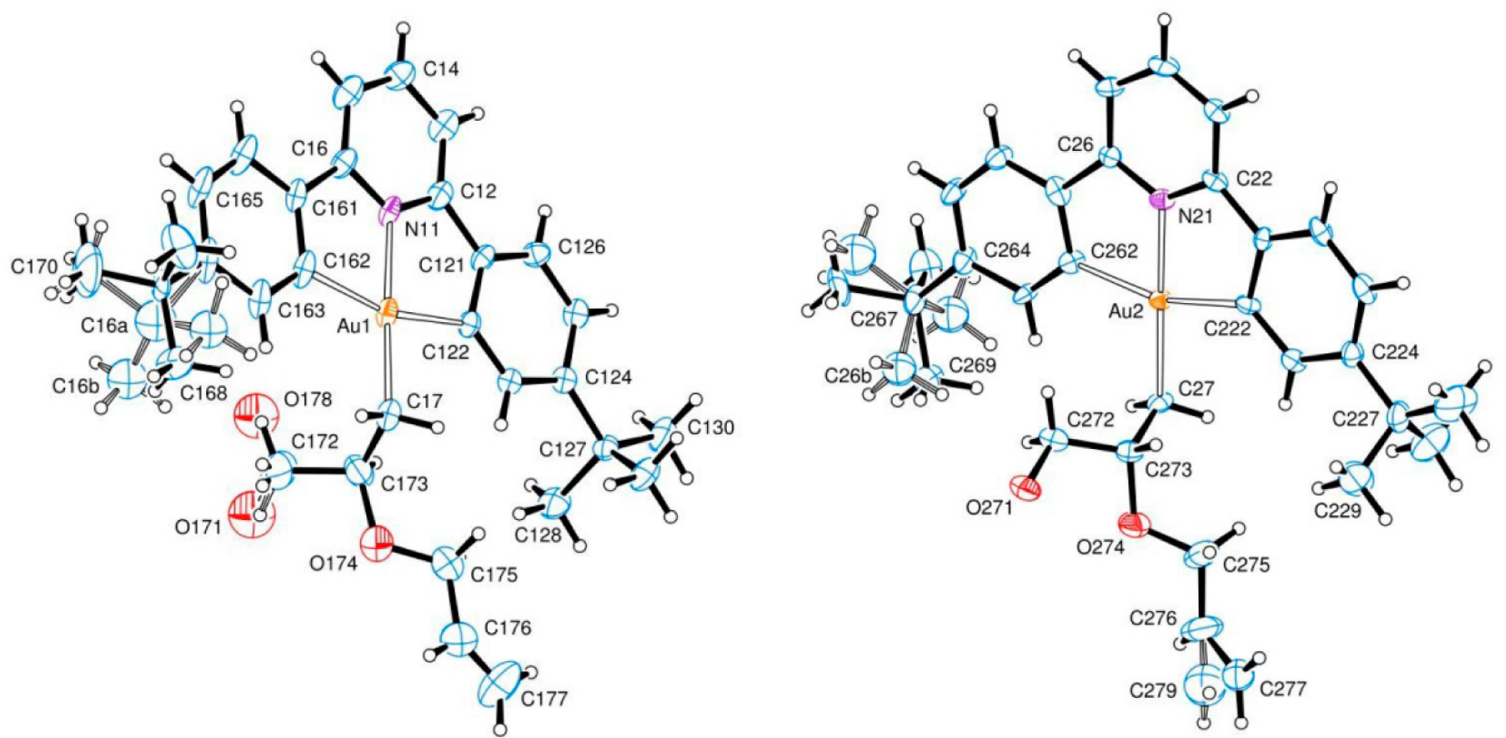

Figure 3. Structure of complex 11, showing the two independent molecules. Selected bond distances $(\AA)$ and angles (deg) for molecule 1: Au(1)$\mathrm{N}(11)$ 2.034(8), $\mathrm{Au}(1)-\mathrm{C}(17)$ 2.057(10), $\mathrm{Au}(1)-\mathrm{C}(122)$ 2.083(8), $\mathrm{Au}(1)-\mathrm{C}(162)$ 2.084(9), C(17) $-\mathrm{C}(173)$ 1.503(15), O(171) $-\mathrm{C}(172)$ 1.36(3), $\mathrm{C}(172)-\mathrm{C}(173) 1.505(18), \mathrm{O}(178)-\mathrm{C}(172) 1.35(3), \mathrm{C}(173)-\mathrm{O}(174) 1.460(14), \mathrm{O}(174)-\mathrm{C}(175) 1.394(14), \mathrm{C}(175)-\mathrm{C}(176) 1.48(2)$, $\mathrm{C}(176)-\mathrm{C}(177)$ 1.22(2); N(11)-Au(1)-C(17) 177.3(3), N(11)-Au(1)-C(122) 81.1(3), C(17)-Au(1)-C(122) 97.6(4), N(11)-Au(1)$\mathrm{C}(162)$ 80.8(4), C(17)-Au(1)-C(162) 100.5(4), C(122)-Au(1)-C(162) 161.8(4).

separated and isolated by chromatography. Compound $\mathbf{1 0}$ was obtained only in trace amounts and identified as the gold(III) 3-propanalyl complex, formed by the isomerization of the allyl alcoholate to the aldehyde. The main product $\mathbf{1 1}$ proved to be the result of allyl alcohol dimerization (Scheme 3). Compound 10 appears to be light sensitive in solution; it gradually turns purple under ambient light and could not be crystallized, whereas crystals of compound $\mathbf{1 1}$ were obtained by slow evaporation of a toluene solution. The analogous reaction of $\left(\mathrm{C}^{\wedge} \mathrm{N}^{\wedge} \mathrm{C}\right) \mathrm{AuOH}$ with methallyl alcohol also led to isomerization and formation of the gold alkyl 12; however, in this case the presence of the methyl side chain prevents the addition of a second alcohol molecule.

The crystal structure of 11 (Figure 3 ) confirms the ${ }^{1} \mathrm{H}$ NMR spectroscopic assignments. The unit cell contains two independent, albeit similar, molecules which show disorder in one of the ${ }^{t} \mathrm{Bu}$ substituents. Also, in molecule 1 , the $-\mathrm{CH}_{2} \mathrm{OH}$ moiety is disordered over two positions, by rotation about the $\mathrm{C}(172)-\mathrm{C}(173)$ bond; in molecule 2 the terminal $-\mathrm{CH}=\mathrm{CH}_{2}$ vinyl group is disordered, principally by rotation about the $\mathrm{C}(275)-\mathrm{C}(276)$ bond. The two molecules lie adjacent and are overlapping (ca. $3.4 \AA$ apart, with the gold atoms $3.619 \AA$ apart).
The two molecules shown are of opposite chirality; there are other pairs of molecules, related through centers of symmetry, with the opposite pairs of chiral centers. None of the hydroxyl hydrogen atoms has been located; that on O271 has no apparent hydrogen-bonding acceptor available, but those on O171 and O178 are likely to be linked with a symmetry-related group.

The metal-mediated isomerization of allyl alcohol to propionaldehyde, and the coupling and isomerization of allyl alcohol with acetylenes are of course well-known. ${ }^{16-18}$ However, whereas in the case of the iron carbonyl mediated isomerization $\eta^{3}$-allyl intermediates have been postulated, the rigid, coordinatively saturated structure of $\left(\mathrm{C}^{\wedge} \mathrm{N}^{\wedge} \mathrm{C}\right) \mathrm{AuOR}$ pincer complexes does not permit such a bonding mode. Instead, a Claisen-type rearrangement can be envisaged (eq 4). In view of the coordinatively saturated nature of $\left(\mathrm{C}^{\wedge} \mathrm{N}^{\wedge} \mathrm{C}\right) \mathrm{AuX}$ compounds, the involvement of $\mathrm{Au}-\mathrm{O}$ bond homolysis and $\mathrm{Au}$ (II) radicals cannot be ruled out.

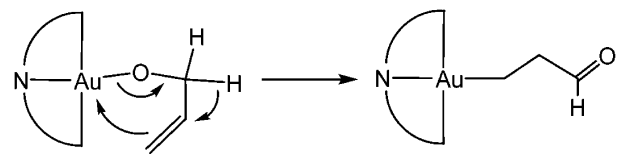




\section{CONCLUSION}

Gold(III) alkoxides show reaction patterns that are driven by the relative weakness of the $\mathrm{Au}-\mathrm{O}$ bond. The pincer-stabilized gold methoxide $\left(\mathrm{C}^{\wedge} \mathrm{N}^{\wedge} \mathrm{C}\right) \mathrm{AuOMe}$ undergoes an $\mathrm{O}$ abstraction reaction with phosphines, leading to the corresponding gold methyl $\left(\mathrm{C}^{\wedge} \mathrm{N}^{\wedge} \mathrm{C}\right)$ AuMe and phosphine oxide, although there are indications that odd-electron intermediates such as $\left(\mathrm{C}^{\wedge} \mathrm{N}^{\wedge} \mathrm{C}\right) \mathrm{Au}^{\mathrm{II}} \bullet$ may also play a role. Most other alkoxides tested under the same conditions give almost exclusively reduction to $\left[\mathrm{Au}\left(\mathrm{C}^{\wedge} \mathrm{N}^{\wedge} \mathrm{C}\right)\right]_{2}$. On the other hand, the attempted synthesis of allyl alcohol derivatives $\left(\mathrm{C}^{\wedge} \mathrm{N}^{\wedge} \mathrm{C}\right) \mathrm{AuOCH}_{2} \mathrm{CH}=$ $\mathrm{CH}_{2}$ led to isomerization and formation of functionalized gold(III) alkyls. These reactions provide therefore a facile onestep method for the generation of gold alkyls carrying functional groups with $-\mathrm{CHO}$ or $-\mathrm{CH}_{2} \mathrm{OH}$ termini, which are not accessible by conventional alkylation routes. Whereas catalytic allyl alcohol isomerization is well-known, the application of this process to the generation of functionalized metal alkyl complexes has, to our knowledge, not been observed before. The thermodynamic driving force for these $\mathrm{O}$-abstraction and isomerization reactions is undoubtedly the difference between the $\mathrm{Au}-\mathrm{C}$ and $\mathrm{Au}-\mathrm{O}$ bond dissociation energies.

\section{EXPERIMENTAL SECTION}

General Considerations. Unless stated otherwise, all reactions were carried out in air. Solvents were distilled and dried as required. $\left(\mathrm{C}^{\wedge} \mathrm{N}^{\wedge} \mathrm{C}\right) \mathrm{AuOH},\left(\mathrm{C}^{\wedge} \mathrm{N}^{\wedge} \mathrm{C}\right) \mathrm{AuOMe}$, and $\left(\mathrm{C}^{\wedge} \mathrm{N}^{\wedge} \mathrm{C}\right) \mathrm{AuOAc}^{\mathrm{F}}$ were obtained according to literature procedures. ${ }^{14}{ }^{1} \mathrm{H},{ }^{13} \mathrm{C}\left\{{ }^{1} \mathrm{H}\right\},{ }^{19} \mathrm{~F}$, and ${ }^{31} \mathrm{P}\left\{{ }^{1} \mathrm{H}\right\}$ NMR spectra were recorded using a Bruker Avance DPX-300 $\mathrm{MHz}$ NMR spectrometer. ${ }^{1} \mathrm{H}$ NMR spectra $(300.13 \mathrm{MHz})$ and ${ }^{13} \mathrm{C}\left\{{ }^{1} \mathrm{H}\right\}(75.47 \mathrm{MHz})$ were referenced to $\mathrm{CD}_{2} \mathrm{Cl}_{2}$ at $\delta 5.32\left({ }^{13} \mathrm{C}\right.$, $\delta$ 54.0) and $\mathrm{C}_{6} \mathrm{D}_{6}$ at $\delta 7.16\left({ }^{13} \mathrm{C}, \delta 128.4\right) .{ }^{19} \mathrm{~F}$ NMR spectra $(282.4$ $\mathrm{MHz}$ ) were referenced externally to $\mathrm{CFCl}_{3}$ and internally to $\mathrm{C}_{6} \mathrm{~F}_{6}$ $\left(\delta_{\mathrm{F}}-164.9\right) .{ }^{31} \mathrm{P}$ NMR spectra $(121.5 \mathrm{MHz})$ were referenced internally to trimethylphosphate $\left(\delta_{\mathrm{P}} 0.0\right)$. IR spectra were recorded using a PerkinElmer Spectrum One FT-IR spectrometer equipped with a diamond ATR attachment. MALDI-TOF mass spectra were measured using a Shimadzu Biotech MALDI mass spectrometer using trans2-[3-(4-tert-butylphenyl)-2-methyl-2-propenylidene]malononitrile (DCTB) as matrix. Elemental analyses were performed by the London Metropolitan University.

Synthesis of $\left(\mathbf{C}^{\wedge} \mathbf{N}^{\wedge} \mathbf{C}\right)$ AuOEt (4). To a suspension of $\mathrm{NaH}(60 \%$ in mineral oil, $30 \mathrm{mg}, 0.75 \mathrm{mmol})$ under $\mathrm{N}_{2}$ in THF $(4 \mathrm{~mL})$ was added dropwise excess EtOH $(0.1 \mathrm{~mL}, 1.7 \mathrm{mmol})$. This was stirred for $30 \mathrm{~min}$ at room temperature. A $1 \mathrm{~mL}$ aliquot of this solution was added to a solution of $\left(\mathrm{C}^{\wedge} \mathrm{N}^{\wedge} \mathrm{C}\right) \mathrm{AuCl}(50 \mathrm{mg}, 0.087 \mathrm{mmol})$ under $\mathrm{N}_{2}$ in THF $(4 \mathrm{~mL})$ and was stirred $1 \mathrm{~h}$ at room temperature. Water was then added and the precipitate was filtered, washed with water and acetonitrile, and left to dry in air to afford a yellow powder $(38 \mathrm{mg}$, $75 \%) .{ }^{1} \mathrm{H}$ NMR $\left(\mathrm{CD}_{2} \mathrm{Cl}_{2}, 300 \mathrm{MHz}\right): \delta 7.81\left(\mathrm{~d}, 2 \mathrm{H}\left(\mathrm{H}_{8}\right), J=2 \mathrm{~Hz}\right)$, $7.78\left(\mathrm{t}, 1 \mathrm{H}\left(H_{1}\right), J=8 \mathrm{~Hz}\right), 7.48\left(\mathrm{~d}, 2 \mathrm{H}\left(H_{5}\right), J=8.5 \mathrm{~Hz}\right), 7.37(\mathrm{~d}, 2 \mathrm{H}$ $\left.\left(H_{2}\right), J=8 \mathrm{~Hz}\right), 7.28\left(\mathrm{dd}, 2 \mathrm{H}\left(H_{6}\right), J_{1}=2 \mathrm{~Hz}, J_{2}=8 \mathrm{~Hz}\right), 4.24(\mathrm{q}, 2 \mathrm{H}$ $\left.\left(\mathrm{OCH}_{2} \mathrm{CH}_{3}\right), J=6.7 \mathrm{~Hz}\right), 1.39\left(\mathrm{t}, 3 \mathrm{H}\left(\mathrm{OCH}_{2} \mathrm{CH}_{3}\right), J=6.8 \mathrm{~Hz}\right), 1.37$ $\left(\mathrm{s}, 18 \mathrm{H}\left(\mathrm{C}\left(\mathrm{CH}_{3}\right)_{3}\right) \mathrm{ppm} .{ }^{1} \mathrm{H}\right.$ NMR $\left(\mathrm{C}_{6} \mathrm{D}_{6}, 300 \mathrm{MHz}\right): \delta 8.35(\mathrm{~d}, 2 \mathrm{H}$, $J=2 \mathrm{~Hz}), 7.20\left(\mathrm{dd}, 2 \mathrm{H}, J_{1}=8.1 \mathrm{~Hz}, J_{2}=2 \mathrm{~Hz}\right), 7.1(\mathrm{~d}, 2 \mathrm{H}, J=$ $8.2 \mathrm{~Hz}), 6.66-6.71(\mathrm{~m}, 1 \mathrm{H}), 6.45(\mathrm{~d}, 2 \mathrm{H}, J=7.9 \mathrm{~Hz}), 4.81(\mathrm{q}, 2 \mathrm{H}, J=$ $6.6 \mathrm{~Hz}), 1.79(\mathrm{t}, 3 \mathrm{H}, J=6.8 \mathrm{~Hz}), 1.34(\mathrm{~s}, 18 \mathrm{H}) \mathrm{ppm} .{ }^{13} \mathrm{C}\left\{{ }^{1} \mathrm{H}\right\} \mathrm{NMR}$ $\left(\mathrm{CD}_{2} \mathrm{Cl}_{2}, 75 \mathrm{MHz}\right) 170.6\left(\mathrm{C}^{\wedge} \mathrm{N}^{\wedge} \mathrm{C}\right.$ ipso $), 164.4\left(\mathrm{C}^{\wedge} \mathrm{N}^{\wedge} \mathrm{C}\right.$ ipso $), 154.7$ ( $\mathrm{C}^{\wedge} \mathrm{N}^{\wedge} \mathrm{C}$ ipso), $145.2\left(\mathrm{C}^{\wedge} \mathrm{N}^{\wedge} \mathrm{C}\right.$ ipso), $142.2\left(C_{1}\right), 129.6\left(C_{8}\right), 124.5$ $\left(C_{5}\right), 123.9\left(C_{6}\right), 115.9\left(C_{2}\right), 66.9\left(\mathrm{OCH}_{2} \mathrm{CH}_{3}\right), 35.3\left(C_{10}\right), 30.9\left(C_{11}\right)$, $21.9\left(\mathrm{OCH}_{2} \mathrm{CH}_{3}\right)$ ppm. Anal. Calcd for $\mathrm{C}_{27} \mathrm{H}_{32} \mathrm{AuNO}$ (found): C, 55.58 (56.06); H, 5.53 (6.23); N, 2.4 (2.28).

Synthesis of $\left(\mathbf{C}^{\wedge} \mathbf{N}^{\wedge} \mathbf{C}\right) \mathrm{AuO} \mathrm{O}^{t} \mathrm{Bu}(5)$. To a suspension of $\mathrm{NaH}(60 \%$ in mineral oil, $35 \mathrm{mg}, 0.9 \mathrm{mmol})$ under $\mathrm{N}_{2}$ in THF $(3 \mathrm{~mL})$ was added dropwise excess tert-butyl alcohol $(0.2 \mathrm{~mL}, 2.1 \mathrm{mmol})$. The mixture was stirred for $3 \mathrm{~h}$ at room temperature. Some of this solution $(1 \mathrm{~mL})$ was added to a solution of $\left(\mathrm{C}^{\wedge} \mathrm{N}^{\wedge} \mathrm{C}\right) \mathrm{AuCl}(50 \mathrm{mg}, 0.087 \mathrm{mmol})$ under $\mathrm{N}_{2}$ in THF $(3 \mathrm{~mL})$ and was stirred for $1 \mathrm{~h}$ at room temperature. Water was then added and the precipitate was filtered and washed with water followed by acetonitrile. The residue was left to dry in air, to afford the product as a yellow powder (49 mg, 92\%). The compound slowly hydrolyzes in air to form the corresponding gold hydroxide $\left(\mathrm{C}^{\wedge} \mathrm{N}^{\wedge} \mathrm{C}\right) \mathrm{AuOH} .{ }^{1} \mathrm{H}$ NMR $\left(\mathrm{CD}_{2} \mathrm{Cl}_{2}, 300 \mathrm{MHz}\right): \delta 7.96(\mathrm{~d}, 2 \mathrm{H}$ $\left.\left(H_{8}\right), J=2 \mathrm{~Hz}\right), 7.79\left(\mathrm{t}, 1 \mathrm{H}\left(H_{1}\right), J=8 \mathrm{~Hz}\right), 7.49\left(\mathrm{~d}, 2 \mathrm{H}\left(H_{5}\right), J=\right.$ $8.1 \mathrm{~Hz}), 7.4\left(\mathrm{~d}, 2 \mathrm{H}\left(\mathrm{H}_{2}\right), J=8 \mathrm{~Hz}\right), 7.27\left(\mathrm{dd}, 2 \mathrm{H}\left(H_{6}\right), J_{1}=2.1 \mathrm{~Hz}\right.$, $\left.J_{2}=8.1 \mathrm{~Hz}\right), 1.47\left(\mathrm{~s}, 9 \mathrm{H}\left(\mathrm{OC}\left(\mathrm{CH}_{3}\right)_{3}\right)\right), 1.36\left(\mathrm{~s}, 18 \mathrm{H}\left(\mathrm{C}\left(\mathrm{CH}_{3}\right)_{3}\right)\right)$ ppm. ${ }^{1} \mathrm{H}$ NMR $\left(\mathrm{C}_{6} \mathrm{D}_{6}, 300 \mathrm{MHz}\right): \delta 8.48(\mathrm{~d}, 2 \mathrm{H}, J=2 \mathrm{~Hz}), 7.19(\mathrm{dd}$, $\left.2 \mathrm{H}, J_{1}=8.1 \mathrm{~Hz}, J_{2}=2 \mathrm{~Hz}\right), 7.09(\mathrm{~d}, 2 \mathrm{H}, J=8.1 \mathrm{~Hz}), 6.59-6.65(\mathrm{~m}$, $1 \mathrm{H}), 6.43(\mathrm{~d}, 2 \mathrm{H}, J=8 \mathrm{~Hz}), 1.88(\mathrm{~s}, 9 \mathrm{H}), 1.35(\mathrm{~s}, 18 \mathrm{H}) \mathrm{ppm} .{ }^{13} \mathrm{C}\left\{{ }^{1} \mathrm{H}\right\}$ NMR $\left(\mathrm{CD}_{2} \mathrm{Cl}_{2}, 75 \mathrm{MHz}\right) 171.7\left(\mathrm{C}^{\wedge} \mathrm{N}^{\wedge} \mathrm{C}\right.$ ipso $), 164.6\left(\mathrm{C}^{\wedge} \mathrm{N}^{\wedge} \mathrm{C}\right.$ ipso $)$, $154.4\left(\mathrm{C}^{\wedge} \mathrm{N}^{\wedge} \mathrm{C}\right.$ ipso $), 145.2\left(\mathrm{C}^{\wedge} \mathrm{N}^{\wedge} \mathrm{C}\right.$ ipso $), 142.3\left(C_{1}\right), 131.9\left(C_{8}\right)$, $124.3\left(C_{5}\right), 123.7\left(C_{6}\right), 115.9\left(C_{2}\right), 74.3\left(\mathrm{OC}\left(\mathrm{CH}_{3}\right)_{3}\right), 35.4\left(C_{10}\right), 34.8$ $\left(\mathrm{OC}\left(\mathrm{CH}_{3}\right)_{3}\right), 30.9\left(\mathrm{C}_{11}\right) \mathrm{ppm}$. Anal. Calcd for $\mathrm{C}_{29} \mathrm{H}_{36} \mathrm{AuNO}$ (found): C, 56.95 (56.71); H, 5.93 (6.11); N, 2.29 (2.30).

Synthesis of $\left(C^{\wedge} N^{\wedge} C\right) A u O\left(C_{6} H_{4} F-p\right)(6)$. To a suspension of $\mathrm{NaH}$ ( $60 \%$ in mineral oil, $30 \mathrm{mg}, 0.75 \mathrm{mmol}$ ) under $\mathrm{N}_{2}$ in THF $(3 \mathrm{~mL})$ was added dropwise $p$-fluorophenol $(100 \mathrm{mg}, 0.8 \mathrm{mmol})$ in THF $(3 \mathrm{~mL})$. This was stirred for $30 \mathrm{~min}$ at room temperature. This solution was added to a solution of $\left(\mathrm{C}^{\wedge} \mathrm{N}^{\wedge} \mathrm{C}\right) \mathrm{AuCl}(150 \mathrm{mg}, 0.24 \mathrm{mmol})$ under $\mathrm{N}_{2}$ in THF $(3 \mathrm{~mL})$, and the resulting mixture was stirred for $3 \mathrm{~h}$ at room temperature. Water was subsequently added and the precipitate was filtered, washed with water followed by acetonitrile, and left to dry in air to afford a yellow solid (160 mg, 100\%). ${ }^{1} \mathrm{H}$ NMR $\left(\mathrm{CD}_{2} \mathrm{Cl}_{2}, 300\right.$ $\mathrm{MHz}): \delta 7.83\left(\mathrm{t}, 1 \mathrm{H}\left(H_{1}\right), J=8.1 \mathrm{~Hz}\right), 7.49\left(\mathrm{~d}, 2 \mathrm{H}\left(H_{5}\right), J=8.2 \mathrm{~Hz}\right)$, $7.4\left(\mathrm{~d}, 2 \mathrm{H}\left(\mathrm{H}_{2}\right), J=8.2 \mathrm{~Hz}\right), 7.34\left(\mathrm{~d}, 2 \mathrm{H}\left(\mathrm{H}_{8}\right), J=2 \mathrm{~Hz}\right), 7.25$ (dd, $\left.2 \mathrm{H}\left(H_{6}\right), J_{1}=2 \mathrm{~Hz}, J_{2}=8.3 \mathrm{~Hz}\right), 6.97-7.01\left(\mathrm{~m}, 2 \mathrm{H}\left(p-\mathrm{FC}_{6} \mathrm{H}_{4}\right)\right)$, 6.81-6.87 (m, 2H $\left.\left(p-\mathrm{FC}_{6} \mathrm{H}_{4}\right)\right), 1.23\left(\mathrm{~s}, 18 \mathrm{H}\left(\mathrm{C}\left(\mathrm{CH}_{3}\right)_{3}\right)\right) \mathrm{ppm} .{ }^{19} \mathrm{~F}$ NMR $\left(\mathrm{CD}_{2} \mathrm{Cl}_{2}, 282.4 \mathrm{MHz}\right): \delta-129.35$ (hept, $\left.J=4.1 \mathrm{~Hz}\right) \mathrm{ppm} .{ }^{1} \mathrm{H}$ NMR $\left(\mathrm{C}_{6} \mathrm{D}_{6}, 300 \mathrm{MHz}\right): \delta 7.88(\mathrm{~d}, 2 \mathrm{H}, J=1.9 \mathrm{~Hz}), 7.32-7.36(\mathrm{~m}$, $2 \mathrm{H}), 7.22\left(\mathrm{dd}, 2 \mathrm{H}, J_{1}=2 \mathrm{~Hz}, J_{2}=8 \mathrm{~Hz}\right), 7.13(\mathrm{~d}, 2 \mathrm{H}, J=8 \mathrm{~Hz}), 6.97-$ $7.02(\mathrm{~m}, 2 \mathrm{H}), 6.77(\mathrm{t}, 1 \mathrm{H}, J=8 \mathrm{~Hz}), 6.49(\mathrm{~d}, 2 \mathrm{H}, J=8 \mathrm{~Hz}), 1.27$ $(\mathrm{s}, 18 \mathrm{H})$ ppm. ${ }^{19} \mathrm{~F}$ NMR $\left(\mathrm{C}_{6} \mathrm{D}_{6}, 282.4 \mathrm{MHz}\right): \delta-128.04$ (hept, $J=$ $4.1 \mathrm{~Hz})$ ppm. ${ }^{13} \mathrm{C}\left\{{ }^{1} \mathrm{H}\right\} \mathrm{NMR}\left(\mathrm{CD}_{2} \mathrm{Cl}_{2}, 75 \mathrm{MHz}\right) 170.3\left(\mathrm{C}^{\wedge} \mathrm{N}^{\wedge} \mathrm{C}\right.$ ipso), $164.9\left(\mathrm{C}^{\wedge} \mathrm{N}^{\wedge} \mathrm{C}\right.$ ipso), $155.1\left(\mathrm{C}^{\wedge} \mathrm{N}^{\wedge} \mathrm{C}\right.$ ipso), $144.7\left(\mathrm{C}^{\wedge} \mathrm{N}^{\wedge} \mathrm{C}\right.$ ipso), $142.8\left(C_{1}\right), 130.0\left(C_{8}\right), 124.6\left(C_{5}\right), 124.2\left(C_{6}\right), 121.0\left(\mathrm{O}-p \mathrm{FC}_{6} \mathrm{H}_{4}\right)$, $120.9\left(\mathrm{O}-p \mathrm{FC}_{6} \mathrm{H}_{4}\right), 116.2\left(\mathrm{C}_{2}\right), 114.8\left(\mathrm{O}-p \mathrm{FC}_{6} \mathrm{H}_{4}\right), 114.6(\mathrm{O}-$ $\left.p \mathrm{FC}_{6} \mathrm{H}_{4}\right), 35.2\left(C_{10}\right), 30.8\left(C_{11}\right)$ ppm. Anal. Calcd for $\mathrm{C}_{31} \mathrm{H}_{31} \mathrm{AuFNO}$ (found): C, 57.32 (57.37); H, 4.81 (4.89); N, 2.16 (2.22) \%.

Synthesis of $\left(\mathbf{C}^{\wedge} \mathbf{N}^{\wedge} \mathbf{C}\right) \mathrm{AuOCH}_{2} \mathrm{CF}_{3}(7) .\left(\mathrm{C}^{\wedge} \mathrm{N}^{\wedge} \mathrm{C}\right) \mathrm{AuOH}(200 \mathrm{mg}$, $0.36 \mathrm{mmol})$ was stirred in toluene $(10 \mathrm{~mL})$ with excess trifluoroethanol $(0.3 \mathrm{~mL}, 3.9 \mathrm{mmol})$ in the presence of $3 \AA$ molecular sieves for $24 \mathrm{~h}$ at room temperature in the dark. The solvent and excess reagent were removed under vacuum. Dichloromethane was added to the residue, and the mixture was sonicated briefly and filtered. The solvent was removed, the residue was sonicated in hexane, and the solid was filtered to afford yellow $\left(\mathrm{C}^{\wedge} \mathrm{N}^{\wedge} \mathrm{C}\right) \mathrm{AuOCH}_{2} \mathrm{CF}_{3}(130 \mathrm{mg}, 57 \%)$ ${ }^{1} \mathrm{H}$ NMR $\left(\mathrm{CD}_{2} \mathrm{Cl}_{2}, 300 \mathrm{MHz}\right): \delta 7.83\left(\mathrm{t}, 1 \mathrm{H}\left(\mathrm{H}_{1}\right), J=8 \mathrm{~Hz}\right), 7.74$ $\left(\mathrm{d}, 2 \mathrm{H}\left(H_{8}\right), J=2.4 \mathrm{~Hz}\right), 7.51\left(\mathrm{~d}, 2 \mathrm{H}\left(H_{5}\right), J=8.1 \mathrm{~Hz}\right), 7.4(\mathrm{~d}, 2 \mathrm{H}$ $\left.\left(H_{2}\right), J=7.9 \mathrm{~Hz}\right), 7.31\left(\mathrm{dd}, 2 \mathrm{H}\left(H_{6}\right), J_{1}=8.3 \mathrm{~Hz}, J_{2}=1.7 \mathrm{~Hz}\right), 4.54(\mathrm{q}$ $\left.2 \mathrm{H}\left(\mathrm{OCH}_{2} \mathrm{CF}_{3}\right), J=8.8 \mathrm{~Hz}\right), 1.37\left(\mathrm{~s}, 18 \mathrm{H}\left(\mathrm{C}\left(\mathrm{CH}_{3}\right)_{3}\right)\right) \mathrm{ppm} .{ }^{1} \mathrm{H} \mathrm{NMR}$ $\left(\mathrm{C}_{6} \mathrm{D}_{6}, 300 \mathrm{MHz}\right): \delta 8.16(\mathrm{~d}, 2 \mathrm{H}, J=1.75 \mathrm{~Hz}), 7.14-7.17(\mathrm{~m}, 2 \mathrm{H})$, $7.01(\mathrm{~d}, 2 \mathrm{H}, J=8.2 \mathrm{~Hz}), 6.65(\mathrm{t}, 1 \mathrm{H}, J=8.1 \mathrm{~Hz}), 6.36(\mathrm{~d}, 2 \mathrm{H}, J=$ $8 \mathrm{~Hz}), 4.88(\mathrm{q}, 2 \mathrm{H}, J=9 \mathrm{~Hz}), 1.32(\mathrm{~s}, 18 \mathrm{H}) \mathrm{ppm} .{ }^{19} \mathrm{~F} \mathrm{NMR}\left(\mathrm{CD}_{2} \mathrm{Cl}_{2}\right.$, $282.4 \mathrm{MHz}): \delta-76.43(\mathrm{t}, J=8.8 \mathrm{~Hz}) \mathrm{ppm} .{ }^{19} \mathrm{~F}$ NMR $\left(\mathrm{C}_{6} \mathrm{D}_{6}\right.$, $282.4 \mathrm{MHz}): \delta-75.54(\mathrm{t}, J=9.2 \mathrm{~Hz}) \mathrm{ppm} .{ }^{13} \mathrm{C}\left\{{ }^{1} \mathrm{H}\right\} \mathrm{NMR}\left(\mathrm{CD}_{2} \mathrm{Cl}_{2}\right.$, $75 \mathrm{MHz}) 170.7\left(\mathrm{C}^{\wedge} \mathrm{N}^{\wedge} \mathrm{C}\right.$ ipso $), 164.8\left(\mathrm{C}^{\wedge} \mathrm{N}^{\wedge} \mathrm{C}\right.$ ipso $), 155.2\left(\mathrm{C}^{\wedge} \mathrm{N}^{\wedge} \mathrm{C}\right.$ ipso), $144.8\left(\mathrm{C}^{\wedge} \mathrm{N}^{\wedge} \mathrm{C}\right.$ ipso $), 142.7\left(C_{1}\right), 129.3\left(C_{8}\right), 124.7\left(C_{5}\right), 124.2$ $\left(C_{6}\right), 116.2\left(C_{2}\right), 35.3\left(C_{10}\right), 30.9\left(C_{11}\right), 30.8\left(\mathrm{OCH}_{2} \mathrm{CF}_{3}\right), \mathrm{ppm} .\left(\mathrm{CF}_{3}\right.$ not observed). Anal. Calcd for $\mathrm{C}_{27} \mathrm{H}_{29} \mathrm{~F}_{3} \mathrm{AuNO}$ (found): $\mathrm{C}, 50.87$ (50.15); H, 4.59 (4.52); N, 2.2 (2.64).

Synthesis of $\left(\mathbf{C}^{\wedge} \mathbf{N}^{\wedge} \mathbf{C}\right) \mathrm{AuOCH}\left(\mathrm{CF}_{3}\right)_{2}$ (8). $\left(\mathrm{C}^{\wedge} \mathrm{N}^{\wedge} \mathrm{C}\right) \mathrm{AuOH}(150 \mathrm{mg}$ $0.27 \mathrm{mmol}$ ) was stirred in toluene $(10 \mathrm{~mL})$ with excess hexafluoroisopropyl alcohol $(0.4 \mathrm{~mL}, 3.8 \mathrm{mmol})$ in the presence of $3 \AA$ molecular sieves for $24 \mathrm{~h}$ at room temperature in the dark. The solvent and excess alcohol were removed under vacuum. Dichloromethane was then added to the residue, and the mixture was sonicated briefly 
and filtered. The solvent was removed, and the residue was taken up in hexane, sonicated, and then filtered to afford the title compound as a yellow powder $(87 \mathrm{mg}, 46 \%) .{ }^{1} \mathrm{H}$ NMR $\left(\mathrm{CD}_{2} \mathrm{Cl}_{2}, 300 \mathrm{MHz}\right): \delta 7.83$ $\left(\mathrm{t}, 1 \mathrm{H}\left(H_{1}\right), J=8 \mathrm{~Hz}\right), 7.66\left(\mathrm{~d}, 2 \mathrm{H}\left(H_{8}\right), J=1.9 \mathrm{~Hz}\right), 4.49(\mathrm{~d}, 2 \mathrm{H}$ $\left.\left(H_{5}\right), J=8.2 \mathrm{~Hz}\right), 4.38\left(\mathrm{~d}, 2 \mathrm{H}\left(H_{2}\right), J=7.9 \mathrm{~Hz}\right), 7.3\left(\mathrm{dd}, 2 \mathrm{H}\left(H_{6}\right), J_{1}=\right.$ $\left.2 \mathrm{~Hz}, J_{2}=8 \mathrm{~Hz}\right), 4.89$ (hept, $\left.1 \mathrm{H}\left(\mathrm{CH}\left(\mathrm{CF}_{3}\right)_{2}\right), J=6 \mathrm{~Hz}\right), 1.35(\mathrm{~s}, 18 \mathrm{H}$ $\left.\left(\mathrm{C}\left(\mathrm{CH}_{3}\right)_{3}\right)\right)$ ppm. ${ }^{13} \mathrm{C}\left\{{ }^{1} \mathrm{H}\right\}$ NMR $\left(\mathrm{CD}_{2} \mathrm{Cl}_{2}, 75 \mathrm{MHz}\right) 170.6\left(\mathrm{C}^{\wedge} \mathrm{N}^{\wedge} \mathrm{C}\right.$ ipso), $165.1\left(\mathrm{C}^{\wedge} \mathrm{N}^{\wedge} \mathrm{C}\right.$ ipso $), 155.5\left(\mathrm{C}^{\wedge} \mathrm{N}^{\wedge} \mathrm{C}\right.$ ipso $), 144.5\left(\mathrm{C}^{\wedge} \mathrm{N}^{\wedge} \mathrm{C}\right.$ ipso), $143.0\left(C_{1}\right), 128.7\left(C_{8}\right), 124.8\left(C_{5}\right), 124.5\left(C_{6}\right), 116.3\left(C_{2}\right), 35.4$ $\left(C_{10}\right), 30.9\left(C_{11}\right), 30.8\left(\mathrm{OCH}\left(\mathrm{CF}_{3}\right)_{2}\right)$ ppm. $\left(\mathrm{CF}_{3}\right.$ not observed $){ }^{19} \mathrm{~F}$ NMR $\left(\mathrm{CD}_{2} \mathrm{Cl}_{2}, 282.4 \mathrm{MHz}\right): \delta-74.9(\mathrm{~d}, \mathrm{~J} 5.1 \mathrm{~Hz})$ ppm. Anal. Calcd for $\mathrm{C}_{28} \mathrm{H}_{28} \mathrm{~F}_{6} \mathrm{AuNO}$ (found): C, 47.67 (47.81); H, 4.0 (3.86); N, 1.99 (2.01).

Synthesis of $\left(C^{\wedge} N^{\wedge} C\right) A u B u^{t}$ (9). To a solution of $\left(C^{\wedge} N^{\wedge} C\right)$ $\operatorname{AuOAc}^{\mathrm{F}}(135 \mathrm{mg}, 0.21 \mathrm{mmol})$ in THF $(5 \mathrm{~mL})$ under $\mathrm{N}_{2}$ was added a solution of tert-butylmagnesium chloride ( $1 \mathrm{M}$ in THF, $210 \mu \mathrm{L}$, $0.21 \mathrm{mmol}$ ) at $-20{ }^{\circ} \mathrm{C}$. The brown solution was stirred for $15 \mathrm{~min}$, and then water was added and the dark solid was filtered. The solid was suspended in DCM, and the solution was sonicated. The solution was then filtered through a cotton plug. The clear solution was evaporated. Hexane was added, and the solution was sonicated and then transferred to a centrifuge tube and centrifuged. The solid that separated is $\left[\mathrm{Au}\left(\mathrm{C}^{\wedge} \mathrm{N}^{\wedge} \mathrm{C}\right)\right]_{2} 3(74 \mathrm{mg}$, 59\%). The solution was transferred to a flask, and the solvent was removed under vacuum to afford a cream-colored solid (44 mg, 35\%). ${ }^{1} \mathrm{H}$ NMR $\left(\mathrm{CD}_{2} \mathrm{Cl}_{2}\right.$, $300 \mathrm{MHz}): \delta 8.21\left(\mathrm{~d}, 2 \mathrm{H}\left(H_{8}\right), J=2 \mathrm{~Hz}\right), 7.67\left(\mathrm{t}, 1 \mathrm{H}\left(H_{1}\right), J=8 \mathrm{~Hz}\right)$, $7.61\left(\mathrm{~d}, 2 \mathrm{H}\left(\mathrm{H}_{5}\right), J=8 \mathrm{~Hz}\right), 7.49\left(\mathrm{~d}, 2 \mathrm{H}\left(\mathrm{H}_{2}\right), J=8 \mathrm{~Hz}\right), 7.27(\mathrm{dd}, 2 \mathrm{H}$ $\left.\left(H_{6}\right), J_{1}=2 \mathrm{~Hz}, J_{2}=8 \mathrm{~Hz}\right), 1.74\left(\mathrm{~s}, 9 \mathrm{H}\left(\mathrm{AuC}\left(\mathrm{CH}_{3}\right)_{3}\right), 1.37(\mathrm{~s}, 18 \mathrm{H}\right.$ $\left.\left(\mathrm{C}\left(\mathrm{CH}_{3}\right)_{3}\right)\right)$ ppm. ${ }^{13} \mathrm{C}\left\{{ }^{1} \mathrm{H}\right\}$ NMR $\left(\mathrm{CD}_{2} \mathrm{Cl}_{2}, 75 \mathrm{MHz}\right): \delta \quad 169.1$ ( $\mathrm{C}^{\wedge} \mathrm{N}^{\wedge} \mathrm{C}$ ipso), $161.8\left(\mathrm{C}^{\wedge} \mathrm{N}^{\wedge} \mathrm{C}\right.$ ipso), $153.3\left(\mathrm{C}^{\wedge} \mathrm{N}^{\wedge} \mathrm{C}\right.$ ipso), 147.9 $\left(\mathrm{C}^{\wedge} \mathrm{N}^{\wedge} \mathrm{C}\right.$ ipso), $140.8\left(C_{1}\right), 133.2\left(C_{8}\right), 124.7\left(C_{5}\right), 122.9\left(C_{6}\right)$, $115.7\left(\mathrm{C}_{2}\right), 35.2\left(\mathrm{C}_{10}\right), 35.0\left(\mathrm{AuC}\left(\mathrm{CH}_{3}\right)_{3}\right), 34.7\left(\mathrm{AuC}\left(\mathrm{CH}_{3}\right)_{3}\right)$, $31.0\left(C_{11}\right)$ ppm. ATR-IR (neat) 2957.47, 2904.4, 2862.05, 2833.3, 1588.58, 1572.42, 1476.7, 1358.63, 1260.11, 1092.29, 1031.96, 788.91, 733.48, 684.01, $608.08 \mathrm{~cm}^{-1} . \mathrm{m} / z$ (MALDI): $596.35\left[\mathrm{M}+\mathrm{H}^{+}\right]$. Anal. Calcd for $\mathrm{C}_{29} \mathrm{H}_{36} \mathrm{AuN}$ (found): C, 58.48 (58.40); H, 6.09 (6.09); $\mathrm{N}, 2.35$ (2.44).

O Abstraction from $\left(\mathrm{C}^{\wedge} \mathrm{N}^{\wedge} \mathrm{C}\right) \mathrm{AuOMe}(1)$. In an NMR tube under $\mathrm{N}_{2},\left(\mathrm{C}^{\wedge} \mathrm{N}^{\wedge} \mathrm{C}\right)$ AuOMe $(10 \mathrm{mg}, 1.8 \mu \mathrm{mol})$ was dissolved in benzene- $d_{6}$ $(0.4 \mathrm{~mL})$. The ${ }^{1} \mathrm{H}$ NMR spectrum was recorded. $\mathrm{P}(p \text {-tol })_{3}(5.3 \mathrm{mg}$, $1.8 \mathrm{mmol}$ ) was added, and the reaction was monitored by NMR spectroscopy at various time intervals. The ${ }^{1} \mathrm{H}$ NMR spectra show the slow conversion of $\left(\mathrm{C}^{\wedge} \mathrm{N}^{\wedge} \mathrm{C}\right) \mathrm{AuOMe}$ to $\left(\mathrm{C}^{\wedge} \mathrm{N}^{\wedge} \mathrm{C}\right) \mathrm{AuMe}$ as well as the formation of the $\mathrm{Au}(\mathrm{II})$ dimer complex in a 3:1 ratio, respectively. This is exemplified by monitoring the appearance of the $\mathrm{H}_{8}$ aromatic signals at 8.18 and $8.81 \mathrm{ppm}$ for $\left(\mathrm{C}^{\wedge} \mathrm{N}^{\wedge} \mathrm{C}\right) \mathrm{AuMe}(2)$ and $\left[\mathrm{Au}\left(\mathrm{C}^{\wedge} \mathrm{N}^{\wedge} \mathrm{C}\right)\right]_{2}(3)$, respectively, concomitant with the disappearance of the $8.44 \mathrm{ppm} \mathrm{H}_{8}$ signal for $\left(\mathrm{C}^{\wedge} \mathrm{N}^{\wedge} \mathrm{C}\right) \mathrm{AuOMe}$. In addition, the methoxy signal at $4.78 \mathrm{ppm}$ in 1 is slowly replaced by the methyl signal at $1.94 \mathrm{ppm}$ in $\left(\mathrm{C}^{\wedge} \mathrm{N}^{\wedge} \mathrm{C}\right)$ AuMe. The ${ }^{31} \mathrm{P}$ NMR spectra show the conversion of $(p \text {-tol })_{3} \mathrm{P}\left(\delta_{\mathrm{P}}-7.64\right)$ to $(p \text {-tol })_{3} \mathrm{PO}\left(\delta_{\mathrm{P}}+25.3\right)$ and $(p \text {-tol })_{3} \mathrm{P}(\mathrm{OMe})_{2}$ $\left(\delta_{\mathrm{p}}-52.5\right)$.

Reaction of $\left(\mathbf{C}^{\wedge} \mathbf{N}^{\wedge} \mathbf{C}\right)$ AuOH with Allyl Alcohol. $\left(\mathrm{C}^{\wedge} \mathrm{N}^{\wedge} \mathrm{C}\right) \mathrm{AuOH}$ $(130 \mathrm{mg}, 0.23 \mathrm{mmol})$ and allyl alcohol $(0.2 \mathrm{~mL}, 3 \mathrm{mmol})$ were stirred overnight at room temperature under an $\mathrm{N}_{2}$ atmosphere in dry toluene in the presence of $3 \AA$ molecular sieves. The solution was filtered, washed with water, dried $\left(\mathrm{MgSO}_{4}\right)$, and filtered, and the solvent was removed in vacuo to afford a yellow oil. This was chromatographed on silica gel using hexane/ethyl acetate $3 / 2$ as eluent. Trace amounts of a first fraction were separated and identified as compound 10. The compound darkened in solution and on the TLC plate with time. ${ }^{1} \mathrm{H}$ NMR $\left(\mathrm{CD}_{2} \mathrm{Cl}_{2}, 300 \mathrm{MHz}\right): \delta 9.87(\mathrm{t}, 1 \mathrm{H}(\mathrm{CHO}), J=2.5 \mathrm{~Hz}), 7.80(\mathrm{t}$, $\left.1 \mathrm{H}\left(H_{1}\right), J=8 \mathrm{~Hz}\right), 7.70\left(\mathrm{~d}, 2 \mathrm{H}\left(H_{8}\right), J=2 \mathrm{~Hz}\right), 7.59\left(\mathrm{~d}, 2 \mathrm{H}\left(H_{5}\right), J=\right.$ $8 \mathrm{~Hz}), 7.47\left(\mathrm{~d}, 2 \mathrm{H}\left(\mathrm{H}_{2}\right), J=8 \mathrm{~Hz}\right), 7.29\left(\mathrm{dd}, 2 \mathrm{H}\left(\mathrm{H}_{6}\right), J_{1}=2 \mathrm{~Hz}, J_{2}=\right.$ $8 \mathrm{~Hz}), 2.94\left(\mathrm{dt}, 2 \mathrm{H}\left(\mathrm{CH}_{2} \mathrm{CH}_{2} \mathrm{CHO}\right), J_{1}=2.5 \mathrm{~Hz}, J_{2}=7.7 \mathrm{~Hz}\right), 2.06(\mathrm{t}$, $\left.2 \mathrm{H}\left(\mathrm{CH}_{2} \mathrm{CH}_{2} \mathrm{CHO}\right), J=7.7 \mathrm{~Hz}\right), 1.38\left(\mathrm{~s}, 18 \mathrm{H}\left(\mathrm{C}\left(\mathrm{CH}_{3}\right)_{3}\right)\right) \mathrm{ppm}$. ATR-IR (neat): 2955.23, 2865.93, 1718.6, 1588.10, 1564.98, 1477.70, $1259.40,1179.62,1099.64,1035.63,792.96,738.05 \mathrm{~cm}^{-1}$. A second fraction, the main product, was isolated and identified as compound $\mathbf{1 1}$ (65 mg, 43\%). ${ }^{1} \mathrm{H}$ NMR $\left(\mathrm{CD}_{2} \mathrm{Cl}_{2}, 300 \mathrm{MHz}\right): \delta 7.74-7.79(\mathrm{~m}, 3 \mathrm{H}$
$\left.\left(H_{1}+H_{8}\right)\right), 7.57\left(\mathrm{~d}, 2 \mathrm{H}\left(H_{5}\right), J=8 \mathrm{~Hz}\right), 7.44\left(\mathrm{~d}, 2 \mathrm{H}\left(H_{2}\right), J=8 \mathrm{~Hz}\right)$, 7.29 (dd, $\left.2 \mathrm{H}\left(H_{6}\right), J_{1}=2 \mathrm{~Hz}, J_{2}=8 \mathrm{~Hz}\right), 6.00-6.13(\mathrm{~m}, 1 \mathrm{H}), 5.33-5.4$ $(\mathrm{m}, 1 \mathrm{H}), 5.17-5.22(\mathrm{~m}, 1 \mathrm{H}), 4.44-4.51(\mathrm{~m}, 1 \mathrm{H}), 4.13-4.20(\mathrm{~m}, 1 \mathrm{H})$, $3.92-4.00(\mathrm{~m}, 1 \mathrm{H}), 3.76-3.84(\mathrm{~m}, 1 \mathrm{H}), 3.59-3.67(\mathrm{~m}, 1 \mathrm{H}), 2.42-$ $2.46(\mathrm{~m}, 1 \mathrm{H}), 2.14-2.18(\mathrm{~m}, 1 \mathrm{H}), 1.66-1.73(\mathrm{~m}, 1 \mathrm{H}), 1.39(\mathrm{~s}, 18 \mathrm{H})$ ppm. ${ }^{13} \mathrm{C}\left\{{ }^{1} \mathrm{H}\right\}$ NMR $\left(\mathrm{CD}_{2} \mathrm{Cl}_{2}, 75 \mathrm{MHz}\right): \delta 167.0\left(\mathrm{C}^{\wedge} \mathrm{N}^{\wedge} \mathrm{C}\right.$ ipso), $163.2\left(\mathrm{C}^{\wedge} \mathrm{N}^{\wedge} \mathrm{C}\right.$ ipso), $154.7\left(\mathrm{C}^{\wedge} \mathrm{N}^{\wedge} \mathrm{C}\right.$ ipso), $148.7\left(\mathrm{C}^{\wedge} \mathrm{N}^{\wedge} \mathrm{C}\right.$ ipso), $142.1\left(C_{1}\right), 136.5\left(\mathrm{OCH}_{2} \mathrm{CH}=\mathrm{CH}_{2}\right), 131.2\left(C_{8}\right), 125.8\left(C_{5}\right), 124.1$ $\left(C_{6}\right), 116.8\left(C_{2}\right), 83.1\left(\mathrm{OCH}_{2} \mathrm{CH}=\mathrm{CH}_{2}\right), 70.8\left(\mathrm{CH}_{2} \mathrm{OH}\right), 68.8$ $\left(\mathrm{OCH}_{2} \mathrm{CH}=\mathrm{CH}_{2}\right), 36.0\left(C_{10}\right), 31.8\left(C_{11}\right), 24.4\left(\mathrm{AuCH}_{2} \mathrm{CH}\right), 1.6$ $\left(\mathrm{AuCH}_{2}\right)$ ppm. ATR-IR (neat): 2953, 2920, 2867, 1589, 1566, 1478, $1259,1178,1065,1035,796,740,689,612 \mathrm{~cm}^{-1}$. Anal. Calcd for $\mathrm{C}_{31} \mathrm{H}_{38} \mathrm{AuNO}_{2}$ (found): C, 56.97 (56.88); H, 5.86 (5.97); N, 2.14 $(2.29) \% . m / z$ (MALDI): $654.26\left[\mathrm{M}+\mathrm{H}^{+}\right]$. Single crystals of 11 suitable for X-ray diffraction were obtained from slow evaporation of a toluene solution at room temperature.

Reaction of $\left(C^{\wedge} N^{\wedge} C\right) A u O H$ with $\beta$-Methallyl Alcohol. $\left(\mathrm{C}^{\wedge} \mathrm{N}^{\wedge} \mathrm{C}\right) \mathrm{AuOH}(100 \mathrm{mg}, 0.18 \mathrm{mmol})$ and $\beta$-methallyl alcohol $(0.15 \mathrm{~mL}, 1.8 \mathrm{mmol})$ were stirred overnight at room temperature under an $\mathrm{N}_{2}$ atmosphere in dry toluene, in the presence of $3 \AA$ molecular sieves. The solution was filtered, washed with water, dried $\left(\mathrm{MgSO}_{4}\right)$, and filtered. Subsequently, the solvent was removed in vacuo and hexane was added to the residue, followed by sonication. The solid was filtered, dissolved in a small amount of ethyl acetate, and chromatographed on silica gel, with hexane/ethyl acetate $4 / 1$ as eluent, to yield 12 as a yellow powder $(16 \mathrm{mg})$. The hexane filtrate was evaporated to afford a second crop of $\mathbf{1 2}$ (40 $\mathrm{mg}, 51 \%$ overall yield). The compound darkened in solution and on the TLC plate with time. ${ }^{1} \mathrm{H}$ NMR $\left(\mathrm{CD}_{2} \mathrm{Cl}_{2}, 300 \mathrm{MHz}\right): \delta 9.82(\mathrm{~d}, 1 \mathrm{H}(\mathrm{CHO}), J=2.0 \mathrm{~Hz})$, $7.78\left(\mathrm{t}, 1 \mathrm{H}\left(H_{1}\right), J=8 \mathrm{~Hz}\right), 7.69\left(\mathrm{~d}, 2 \mathrm{H}\left(H_{8}\right), J=2 \mathrm{~Hz}\right), 7.58(\mathrm{~d}, 2 \mathrm{H}$ $\left.\left(H_{5}\right), J=8 \mathrm{~Hz}\right), 7.46\left(\mathrm{~d}, 2 \mathrm{H}\left(H_{2}\right), J=8 \mathrm{~Hz}\right), 7.29\left(\mathrm{dd}, 2 \mathrm{H}\left(H_{6}\right), J_{1}=\right.$ $\left.8 \mathrm{~Hz}, J_{2}=2 \mathrm{~Hz}\right), 2.87-2.96(\mathrm{~m}, 1 \mathrm{H}), 2.01-2.09(\mathrm{~m}, 1 \mathrm{H}), 1.85-1.91$ $(\mathrm{m}, 1 \mathrm{H}), 1.38(\mathrm{~s}, 18 \mathrm{H}), 1.29(\mathrm{~d}, 3 \mathrm{H}, J=6.7 \mathrm{~Hz}) \mathrm{ppm} .{ }^{13} \mathrm{C}\left\{{ }^{1} \mathrm{H}\right\} \mathrm{NMR}$ $\left(\mathrm{CD}_{2} \mathrm{Cl}_{2}, 75 \mathrm{MHz}\right): \delta 205.7(\mathrm{CHO}), 167.4\left(\mathrm{C}^{\wedge} \mathrm{N}^{\wedge} \mathrm{C}\right.$ ipso $), 163.1$ ( $\mathrm{C}^{\wedge} \mathrm{N}^{\wedge} \mathrm{C}$ ipso $), 154.7\left(\mathrm{C}^{\wedge} \mathrm{N}^{\wedge} \mathrm{C}\right.$ ipso $), 148.8\left(\mathrm{C}^{\wedge} \mathrm{N}^{\wedge} \mathrm{C}\right.$ ipso $), 142.1\left(C_{1}\right)$, $131.1\left(C_{8}\right), 125.8\left(C_{5}\right), 124.1\left(C_{6}\right), 116.8\left(C_{2}\right), 49.2(\mathrm{CHCHO}), 35.9$ $\left(C_{10}\right), 31.7\left(C_{11}\right), 25.3\left(\mathrm{CH}_{3}\right), 17.9\left(\mathrm{AuCH}_{2}\right)$ ppm. ATR-IR (neat): 2955, 2904, 2866, 1716, 1589, 1566, 1478, 1280, 1260, 1179, 1098, 1037, 796, 739, 689, $612 \mathrm{~cm}^{-1} \cdot \mathrm{m} / z$ (MALDI): $610.40\left[\mathrm{M}+\mathrm{H}^{+}\right]$.

Crystal Structure Analysis of Compound 11. Crystal data: $\mathrm{C}_{31} \mathrm{H}_{38} \mathrm{AuNO}_{2}, M_{\mathrm{r}}=653.59$, monoclinic, space group $I 2 / c$ (No. 15 ), $a=28.8593(4) \AA, b=12.2845(2) \AA, c=33.8899(5) \AA, \beta=104.681(1)^{\circ}$, $V=11622.5(3) \AA^{3} . Z=16, D_{c}=1.494 \mathrm{~g} \mathrm{~cm}^{-3}, F(000)=5216, T=$ $140(1) \mathrm{K}, \mu($ Mo K $\alpha)=50.9 \mathrm{~cm}^{-1}, \lambda($ Mo K $\alpha)=0.71073 \AA$.

Crystals are colorless blocks. One, ca. $0.31 \times 0.17 \times 0.06 \mathrm{~mm}$, was mounted in oil on a glass fiber and fixed in the cold nitrogen stream on an Oxford Diffraction Xcalibur-3/Sapphire3-CCD diffractometer, equipped with Mo $\mathrm{K} \alpha$ radiation and graphite monochromator. Intensity data were measured by thin-slice $\omega$ and $\varphi$ scans. The total number of reflections recorded, to $\theta_{\max }=27.5^{\circ}$, was 97464, 13313 of which were unique $\left(R_{\mathrm{int}}=0.086\right)$; 9821 were "observed" with $I>2 \sigma_{I}$.

Data were processed using the CrysAlisPro-CCD and -RED ${ }^{19}$ programs. The structure was determined by the intrinsic phasing routines in the SHELXT program ${ }^{20}$ and refined by full-matrix leastsquares methods, on $F^{2}$ values, in SHELXL. ${ }^{20}$ There are two independent, but very similar, molecules in this crystal. There is disorder in both molecules. The non-hydrogen atoms in fulloccupation sites were refined with anisotropic thermal parameters; some of the disordered atoms were refined isotropically. The hydroxyl hydrogen atoms were not located or included in any calculations. All other hydrogen atoms were included in idealized positions, and their $U_{\text {iso }}$ values were set to ride on the $U_{\text {eq }}$ values of the parent carbon atoms. At the conclusion of the refinement, $\mathrm{wR} 2=0.144$ and $\mathrm{R} 1=$ $0.087^{20}$ for all 13313 reflections weighted by $w=\left[\sigma^{2}\left(F_{\mathrm{o}}^{2}\right)+\right.$ $\left.(0.0455 P)^{2}+138.22\right]^{-1}$ with $P=\left(F_{o}{ }^{2}+2 F_{c}^{2}\right) / 3$; for the "observed" data only, $\mathrm{R} 1=0.060$. In the final difference map, the highest peak (ca. $3.1 \mathrm{e}^{-3}$ ) was close to a gold atom. Scattering factors for neutral atoms were taken from ref 21 . Computer programs used in this analysis have been noted above and were run through $\mathrm{WinGX}^{22}$ on a Dell Optiplex 780 PC at the University of East Anglia. 


\section{ASSOCIATED CONTENT}

\section{S Supporting Information}

The Supporting Information is available free of charge on the ACS Publications website at DOI: 10.1021/acs.organomet.7b00077. Complete details of the X-ray analyses reported herein have also been deposited at the Cambridge Crystallographic Data Centre (CCDC No. 1528330). These data can be obtained free of charge via www.ccdc.cam.ac.uk/data_request/ cif, by emailing data_request@ccdc.cam.ac.uk, or by contacting the Cambridge Crystallographic Data Centre, 12 Union Road, Cambridge CD2 1EZ, U.K. (fax +44 1223 336033).

Additional experimental details and characterization data and computational details (PDF)

Crystallographic data for $\mathbf{1 1}$ (CIF)

\section{AUTHOR INFORMATION}

\section{Corresponding Authors}

*P.H.M.B.: e-mail, budzelaa@cc.umanitoba.ca.

*M.B.: tel, +44 1603 592044; e-mail, m.bochmann@uea.ac.uk.

\section{ORCID 1}

Manfred Bochmann: 0000-0001-7736-5428

\section{Present Address}

${ }^{\S}$ Dragoş-Adrian Roşca, Max-Planck-Institut für Kohlenforschung, D-45470 Mülheim/Ruhr, Germany.

${ }^{\#}$ Peter H. M. Budzelaar, Department of Chemical Sciences, University of Naples, I-80126 Napoli, Italy. E-mail: p.budzelaar@unina.it.

\section{Notes}

The authors declare no competing financial interest.

\section{ACKNOWLEDGMENTS}

This paper is dedicated to Professor Gerard van Koten on the occasion of his 75th birthday. This work was supported by the University of East Anglia and the European Research Council. D.-A.R. thanks the University of East Anglia for a Ph.D. studentship and a Katritzky scholarship. M.B. is an ERC Advanced Investigator Award holder (grant no. 338944 GOCAT).

\section{REFERENCES}

(1) For recent summaries see for example: (a) Lauterbach, T.; Asiri, A. M.; Hashmi, A. S. K. Adv. Organomet. Chem. 2014, 62, 261-297. (b) Yang, W.; Hashmi, A. S. K. Chem. Soc. Rev. 2014, 43, 2941-2955.

(c) Hashmi, A. S. K. Top. Organomet. Chem. 2012, 44, 143-164.

(d) Liu, L.-P.; Hammond, G. B. Chem. Soc. Rev. 2012, 41, 3129-3139.

(e) Debrouwer, W.; Heugebaert, T. S. A.; Roman, B. I.; Stevens, C. V. Adv. Synth. Catal. 2015, 357, 2975-3006. (f) Miró, J.; del Pozo, C. Chem. Rev. 2016, 116, 11924-11966. (g) Zi, W. W.; Toste, F. D. Chem. Soc. Rev. 2016, 45, 4567-4589.

(2) (a) Fürstner, A.; Davies, P. W. Angew. Chem., Int. Ed. 2007, 46, 3410-3449. (b) Fürstner, A. Chem. Soc. Rev. 2009, 38, 3208-3221. (c) Bandini, M. Chem. Soc. Rev. 2011, 40, 1358-1367.

(3) Schmidbaur, H.; Schier, A. Arab. J. Sci. Engin. 2012, 37, 11871225. (b) Leyva-Perez, A.; Corma, A. Angew. Chem., Int. Ed. 2012, 51, 614-635. (c) Boorman, T. C.; Larrosa, I. Chem. Soc. Rev. 2011, 40, $1910-1925$

(4) Recent reviews: (a) Joost, M.; Amgoune, A.; Bourissou, D. Angew. Chem., Int. Ed. 2015, 54, 15022-15045. (b) Kumar, R.; Nevado, C. Angew. Chem., Int. Ed. 2017, 56, 1994-2015. (c) de Haro, T.; Nevado, C. Synthesis 2011, 2011, 2530-2539.

(5) See for example: (a) Rekhroukh, F.; Estevez, L.; Mallet-Ladeira, S.; Miqueu, K.; Amgoune, A.; Bourissou, D. J. Am. Chem. Soc. 2016, 138, 11920-11929. (b) Rekhroukh, F.; Estevez, L.; Bijani, C.; Miqueu,
K.; Amgoune, A.; Bourissou, D. Organometallics 2016, 35, 995-1001. (c) Tlahuext-Aca, A.; Hopkinson, M. N.; Daniliuc, C. G.; Glorius, F. Chem. - Eur. J. 2016, 22, 11587-11592. (d) Winston, M. S.; Wolf, W. J.; Toste, F. D. J. Am. Chem. Soc. 2014, 136, 7777-7782. (e) Winston, M. S.; Wolf, W. J.; Toste, F. D. J. Am. Chem. Soc. 2015, 137, 79217928. (f) Kawai, H.; Wolf, W. J.; DiPasquale, A. G.; Winston, M. S.; Toste, F. D. J. Am. Chem. Soc. 2016, 138, 587-593. (g) Wolf, W. J.; Winston, M. S.; Toste, F. D. Nat. Chem. 2013, 6, 159-164. (h) Kaphan, D. M.; Levin, M. D.; Bergman, R. G.; Raymond, K. N.; Toste, F. D. Science 2015, 350, 1235-1238. (i) Nijamudheen, A.; Karmakar, S.; Datta, A. Chem. - Eur. J. 2014, 20, 14650-14658. (j) Ghosh, M. K.; Tilset, M.; Venugopal, A.; Heyn, R. H.; Swang, O. J. Phys. Chem. A 2010, 114, 8135-8141. (k) Corrie, T. J. A.; Ball, L. T.; Russell, C. A.; Lloyd-Jones, G. C. J. Am. Chem. Soc. 2017, 139, 245254.

(6) Roşca, D.-A.; Wright, J. A.; Bochmann, M. Dalton Trans. 2015, 44, 20785-20807.

(7) Roşca, D.-A.; Wright, J. A.; Hughes, D. L.; Bochmann, M. Nat. Commun. 2013, 4, 2167.

(8) Roşca, D.-A.; Fernandez-Cestau, J.; Morris, J.; Wright, J. A.; Bochmann, M. Science Adv. 2015, 1, e1500761.

(9) Smith, D. A.; Roşca, D.-A.; Bochmann, M. Organometallics 2012, $31,5998-6000$

(10) (a) Grochowski, E.; Hilton, B. D.; Kupper, R. J.; Michejda, C. J. J. Am. Chem. Soc. 1982, 104, 6876-6877. (b) Mathieu-Pelta, I.; Evans, S. A., Jr. J. Org. Chem. 1994, 59, 2234-2237.

(11) (a) Roşca, D.-A.; Smith, D. A.; Hughes, D. L.; Bochmann, M. Angew. Chem., Int. Ed. 2012, 51, 10643-10646. (b) Roşca, D.-A.; Bochmann, M. Organometallics 2016, 35, 27-31.

(12) Dann, T.; Roşca, D.-A.; Wildgoose, G. G.; Wright, J. A.; Bochmann, M. Chem. Commun. 2013, 49, 10169-10171.

(13) Pintus, A.; Rocchigiani, L.; Fernandez-Cestau, J.; Budzelaar, P. H. M.; Bochmann, M. Angew. Chem., Int. Ed. 2016, 55, 12321-12324.

(14) Roşca, D.-A.; Smith, D. A.; Bochmann, M. Chem. Commun. 2012, 48, 7247-7249.

(15) The formation of 9 is very sensitive to the reaction conditions. Reacting $\left(\mathrm{C}^{\wedge} \mathrm{N}^{\wedge} \mathrm{C}\right) \mathrm{AuCl}$ with $t-\mathrm{BuMgCl}$ at room temperature gives exclusively 3 , as did mixtures of $\left(\mathrm{C}^{\wedge} \mathrm{N}^{\wedge} \mathrm{C}\right) \mathrm{AuOAc}^{\mathrm{F}}$ and ${ }^{\mathrm{P}} \mathrm{Bu}_{2} \mathrm{Mg}$ at -78 ${ }^{\circ} \mathrm{C}$, whereas the reaction of $\left(\mathrm{C}^{\wedge} \mathrm{N}^{\wedge} \mathrm{C}\right) \mathrm{AuOAc}^{\mathrm{F}}$ and $t$ - $\mathrm{BuMgCl}$ at -78 ${ }^{\circ} \mathrm{C}$ afforded $\left(\mathrm{C}^{\wedge} \mathrm{N}^{\wedge} \mathrm{C}\right) \mathrm{AuCl}$.

(16) (a) Hendrix, W. T.; Cowherd, F. G.; von Rosenberg, J. L. Chem. Commun. 1968, 0, 97-99. (b) Chase, H. M.; McDonough, T. J.; Overly, K. R.; Laperle, C. M. J. Phys. Org. Chem. 2013, 26, 322-326.

(17) Dérien, S.; Dixneuf, P. H. J. Chem. Soc., Chem. Commun. 1994, 2551-2552.

(18) Rüba, E.; Gemel, C.; Slugovc, C.; Mereiter, K.; Schmid, R.; Kirchner, K. Organometallics 1999, 18, 2275-2280.

(19) Programs CrysAlisPro; Oxford Diffraction Ltd., Abingdon, U.K., 2014.

(20) Sheldrick, G. M. SHELX-97 - Programs for crystal structure determination (SHELXT) and refinement (SHELXL). Acta Crystallogr., Sect. A: Found. Crystallogr. 2008, 64, 112-122; Acta Crystallogr., Sect. A: Found. Adv. 2015, 71, 3-8; and Acta Crystallogr. 2015, C71, $3-8$.

(21) International Tables for X-ray Crystallography; Kluwer Academic: Dordrecht, The Netherlands, 1992; Vol. C, pp 500, 219, and 193.

(22) Farrugia, L. J. J. Appl. Crystallogr. 2012, 45, 849-854. 